\title{
Identification of new antimicrobial peptides that contribute to the bactericidal activity of egg white against Salmonella enterica serovar Enteritidis at $45^{\circ} \mathrm{C}$
}

Article

Accepted Version

Cochet, M.-F., Baron, F., Bonnassie, S., Jan, S., Leconte, N., Jardin, J., Briard-Bion, V., Gautier, M., Andrews, S. C., GuérinDubiard, C. and Nau, F. (2021) Identification of new antimicrobial peptides that contribute to the bactericidal activity of egg white against Salmonella enterica serovar Enteritidis at $45^{\circ} \mathrm{C}$. Journal of Agricultural and Food Chemistry, 69 (7). pp. 2118-2128. ISSN 0021-8561 doi: https://doi.org/10.1021/acs.jafc.0c06677 Available at https://centaur.reading.ac.uk/96166/

It is advisable to refer to the publisher's version if you intend to cite from the work. See Guidance on citing.

To link to this article DOI: http://dx.doi.org/10.1021/acs.jafc.0c06677

Publisher: American Chemical Society

All outputs in CentAUR are protected by Intellectual Property Rights law, including copyright law. Copyright and IPR is retained by the creators or other copyright holders. Terms and conditions for use of this material are defined in 
the End User Agreement.

www.reading.ac.uk/centaur

\section{CentAUR}

Central Archive at the University of Reading

Reading's research outputs online 
Identification of new anti-microbial peptides that contribute to the bactericidal activity of egg white against Salmonella enterica serovar Enteritidis at $45^{\circ} \mathrm{C}$

Marie-Françoise Cochet $^{1 *}$, Florence Baron $^{1}$, Sylvie Bonnassie ${ }^{1,2}$, Sophie Jan $^{1}$, Nadine Leconte $^{1}$, Julien Jardin ${ }^{1}$, Valérie Briard-Bion ${ }^{1}$, Michel Gautier ${ }^{1}$, Simon C. Andrews ${ }^{3}$, Catherine Guérin-Dubiard ${ }^{1}$, Françoise $\mathrm{Nau}^{1}$

${ }^{1}$ STLO, INRAE, Institut Agro, 35042, Rennes, France

${ }^{2}$ UFR Sciences de la Vie et de l'Environnement, Rennes, France

${ }^{3}$ School of Biological Sciences, Knight Building, University of Reading, Reading, UK 


\section{Abstract}

2 A recent work revealed that egg white $(\mathrm{EW})$ at $45^{\circ} \mathrm{C}$ exhibits a powerful bactericidal activity

3 against $S$. enterica serovar Enteritidis, which is surprisingly little affected by removal of the

$4>10 \mathrm{kDa}$ EW proteins. Here, we sought to identify the major EW factors responsible for this

5 bactericidal activity by fractionating EW using ultrafiltration and nanofiltration, and by

6 characterizing the physicochemical and antimicrobial properties of the resulting fractions. In

7 particular, 22 peptides were identified by nano-LC/MS-MS and the bactericidal activities of

8 representative peptides (with predicted antimicrobial activity) were further assessed. Two

9 peptides (FVPPVQR and GDPSAWSWGAEAHS) were found to be bactericidal against $S$. enterica serovar Enteritidis at $45^{\circ} \mathrm{C}$ when provided in an EW environment. Nevertheless, these

11 peptides contribute only part of this bactericidal activity, suggesting other, yet to be determined, 12 anti-microbial factors.

13 Keywords: egg white; ultrafiltration; antimicrobial activity; peptide; Salmonella 14 Enteritidis 


\section{Introduction}

Egg white (EW) represents a hostile medium for microorganisms due to its alkaline $\mathrm{pH}$, high viscosity, nutrient deficiency and the array of antimicrobial proteins and peptides it contains (in particular lysozyme, ovotransferrin, protease inhibitors and vitamin-binding proteins $)^{1,2}$. Lysozyme exerts a hydrolytic activity against the cell wall of Gram-positive bacteria leading to membrane disruption. Ovotransferrin is a high-affinity iron-chelating protein that promotes iron restriction and mediates damage to bacterial cytoplasmic membranes ${ }^{3}$. Protease inhibitors (e.g. ovomucoid, ovoinhibitor, cystatin and ovostatin) would inhibit proteases of pathogenic bacteria required for host colonization. EW vitamin-binding proteins, namely flavoprotein, avidin and the thiamine-binding protein sequester riboflavin, biotin and thiamine, respectively, and thus would induce a bacteriostatic effect. In addition, some minor proteins and peptides recently revealed by high-throughput approaches may also play a role in defence against bacterial contamination and it is quite possible that the various anti-bacterial factors associated with EW interact synergistically to enhance protection against bacterial invaders ${ }^{4}$.

Previous studies on the antimicrobial activity of chicken EW largely focused on Salmonella enterica serovar Enteritidis, hereinafter referred to as $S$. Enteritidis, since this serotype is the major food-borne pathogen (90\%) associated with the consumption of eggs and egg products ${ }^{5}$. The high association of $S$. Enteritidis in egg-related salmonellosis is thought to be due to its specialized ability to survive exposure to the hostile conditions of $\mathrm{EW}^{6-8}$. It is generally accepted that upon exposure to EW Salmonella suffers from two major harmful influences, iron deficiency (resulting in a bacteriostatic effect) and cell-envelop damage (which is bactericidal) ${ }^{4}$. However, physicochemical factors, such as alkaline $\mathrm{pH}$ and temperature of incubation also play important roles in EW antimicrobial activity. Indeed, $S$. Enteritidis is able to grow weakly in EW at $20^{\circ} \mathrm{C}$ and $30{ }^{\circ} \mathrm{C}^{2,9}$. However, at higher temperature $\left(\geq 42{ }^{\circ} \mathrm{C}\right)$, EW exerts a bactericidal effect against $S$. Enteritidis ${ }^{1,6,10}$. It is notable that the lowest temperature at which significant 
bactericidal activity is observed for $\mathrm{EW}$ is close to that naturally encountered during egg formation (i.e. that of the hen body, $42{ }^{\circ} \mathrm{C}$ ). For this reason, this temperature is routinely used in studies on the bactericidal activity of $\mathrm{EW}^{11,12}$. The importance of temperature in the antimicrobial activity of EW is highlighted by a method for pasteurisation of liquid EW involving heat treatment at $42-45^{\circ} \mathrm{C}$ for 1 to 5 days. This treatment allows subsequent storage of EW at room temperature for several months ${ }^{13}$ and, critically, it provides a complete killing of $S$. Enteritidis and is more efficient than the traditional EW pasteurization treatment $\left(57{ }^{\circ} \mathrm{C}\right.$ for 2 to $5 \mathrm{~min}$ ) that requires subsequent storage under refrigeration.

Exposure of $S$. Enteritidis to EW model medium (namely egg white $10 \mathrm{kDa}$ filtrate supplemented with $10 \% \mathrm{EW}$ ) at $45{ }^{\circ} \mathrm{C}$ for 45 min results in extensive changes in global-gene expression $^{10}$ indicative of a major response of $S$. Enteritidis to nutrient deprivation (iron and biotin) and cell damage/stress, and a shift in energy metabolism and catabolism. These changes were considered to reflect attempts by $S$. Enteritidis to overcome the antibacterial activities of EW that lead to eventual cell death after prolonged incubation at $45^{\circ} \mathrm{C}$. Surprisingly, removal of the $\geq 10 \mathrm{kDa}$ proteins from EW by ultrafiltration had little impact on the global expression pattern (only 64 genes were affected after $45 \mathrm{~min}, 2 \%$ of the total genome) and the bactericidal activity (over $24 \mathrm{~h}$ ) when compared to the EW model medium, indicating that the EW proteins of $\geq 10 \mathrm{kDa}$ are not strictly required for the bactericidal activity of $\mathrm{EW}$ at $45^{\circ} \mathrm{C}^{14}$, despite potentially active. In addition, the $\geq 10 \mathrm{kDa}$ proteins of EW were not required for lysis of $S$. Enteritidis in EW at $45{ }^{\circ} \mathrm{C}^{14}$. Thus, it was concluded that low mass $(<10 \mathrm{kDa})$ components of EW (such as minerals and/or small bioactive/antimicrobial peptides) are probably the major contributors to the bactericidal activity of EW at $45^{\circ} \mathrm{C}^{14}$.

The aim of the study presented here was to determine the key low-mass $(<10 \mathrm{kDa})$ factors responsible for Salmonella killing by EW at $45^{\circ} \mathrm{C}$. To identify such factors, successive ultraand nano-filtration steps were applied to EW (10 kDa, $1 \mathrm{kDa}$ and $400 \mathrm{Da}$ cut-off membranes, 
respectively) and the antimicrobial activities and compositions of the resulting filtrates were determined.

\section{Materials and methods}

\section{Bacterial strain}

Salmonella enterica serovar Enteritidis NCTC13349 was kindly provided by Matthew McCusker (Center for Food Safety and Food Borne Zoonomics, Veterinary Sciences Centre, University College Dublin, Ireland). This strain was isolated from an outbreak of human food poisoning in the United Kingdom traced back to a poultry farm. The stock cultures were stored at $-80{ }^{\circ} \mathrm{C}$ in $25 \%(\mathrm{v} / \mathrm{v})$ glycerol. Before use, cells were propagated twice overnight at $37{ }^{\circ} \mathrm{C}$ in tryptic soy broth (TSB, Merck, Darmstadt, Germany) without shaking.

\section{Preparation of sterile egg white}

EW was prepared from 5 to 10 day-old eggs provided from a local supermarket. The eggshell surface was cleaned with a tissue, checked for cracks and then sterilized using $70 \%$ alcohol; residual alcohol was removed by briefly flaming the shell. Eggshells were then broken under sterile conditions and the egg whites were collected before aseptic homogenization with a DI25 Basic homogenizer (Ika, Grosseron, Saint-Herblain, France) at 9,500 rpm for $1 \mathrm{~min}$. The egg white $\mathrm{pH}$ was $9.3 \pm 0.1$.

\section{Egg-white fractionation}

EW ultrafiltration was carried out according to Baron et al. ${ }^{2}$ using a pilot unit (Millipore type PRO LAB MSP 006239) equipped with an organic spiral-wound membrane $\left(0.3 \mathrm{~m}^{2}, 10 \mathrm{kDa}\right.$ cut-off). The concentrated EW (egg white retentate, EWR) was circulated back to the feed-tank while the EW filtrate (10kDa EWF) was drained off and collected in a beaker (Figure 1). The $10 \mathrm{kDa}$ EWF was then either subjected to ultrafiltration (as above) using an organic spiral- 
wound membrane $\left(0.3 \mathrm{~m}^{2}, 1 \mathrm{kDa}\right.$ cut-off) to obtain the $1 \mathrm{kDa} \mathrm{EWF}$, or to nanofiltration with a Helicon Nanomax 50 membrane $\left(0.3 \mathrm{~m}^{2}, 400\right.$ Da cut-off) to obtain the 400Da EWF (Figure 1). All EW filtrates (EWF) were sterilized by filtration (NalgeneR filter unit, pore size $<0.2 \mu \mathrm{m}$, Osi, Elancourt, France), measured for $\mathrm{pH}$ and then stored at $4{ }^{\circ} \mathrm{C}$ until use.

\section{Physicochemical analyses.}

Nitrogen content of EW and EWFs was determined by the Kjeldahl method. Glucose was quantified using an enzymatic spectrophotometric test (Glucose GOD FS) according to the instructions of the provider (DiaSys GmbH, Germany). Mineral quantification by ICP-OES was carried out using samples in 10\% iron-free nitric acid (Sigma-Aldrich; 438073), incubated in sealed, plastic tubes at $80{ }^{\circ} \mathrm{C}$ overnight with occasional vortexing. Samples were centrifuged (4 ${ }^{\circ} \mathrm{C}, 30 \mathrm{~min}, 18,111 \mathrm{~g}$ ) and supernatants were diluted twofold. The multi-elemental contents of the nitric acid-dissolved sample-solutions were determined using a Perkin Elmer Optima 3000 ICP-OES with radial view and a cross flow nebulizer (Anne Dudley, Analytical Technical Services, University of Reading).

\section{Mass spectrometry analysis}

Mass spectrometry (MS) analysis was performed on EW fractions (10kDa EWF, 400Da EWF and 400Da EWR) using a NanoLC Dionex U3000 system fitted to a Q-Exactive mass spectrometer (Thermoscientific, San Jose, USA) equipped with a nano-electrospray ion source. One hundred microliters of samples was diluted in a solution composed of $100 \mu \mathrm{L}$ nano-LC solvent A described below and $50 \mu \mathrm{L}$ of $2 \%$ formic acid. These samples were concentrated on a C18 PepMap100 cartridge (5 $\mu \mathrm{m}$ particle size, $100 \AA$ A pore size, $300 \mu \mathrm{m}$ i.d., $5 \mathrm{~mm}$ length; Dionex, Amsterdam, The Netherlands), before peptide separation on a C18 PepMap100 column (3 $\mu \mathrm{m}$ particle size, $100 \AA$ pore size, $75 \mu \mathrm{m}$ i.d., $150 \mathrm{~mm}$ length; Dionex). Elution was performed using solvent A (2\% v/v acetonitrile, $0.08 \% \mathrm{v} / \mathrm{v}$ formic acid and $0.01 \% \mathrm{v} / \mathrm{v}$ TFA in 
deionized water) and solvent B (95\% v/v acetonitrile, $0.08 \% \mathrm{v} / \mathrm{v}$ formic acid, and $0.01 \% \mathrm{v} / \mathrm{v}$ TFA in deionized water), by applying a gradient from 5 to $70 \%$ solvent B over 28 min followed by a gradient from 70 to $95 \%$ solvent $\mathrm{B}$ over $5 \mathrm{~min}$ at a flow rate of $0.3 \mathrm{~mL} / \mathrm{min}$.

Eluted peptides were directly electro-sprayed into the Proxeon source operating in positive ion mode with an optimized voltage of $2.1 \mathrm{kV}$. The mass spectra were recorded in a $\mathrm{m} / \mathrm{z}$ range from 250 to 2,000 , with a resolution of the mass analyzer set to 70,000. For each scan, the ten most intense ions were selected for fragmentation. MS/MS spectra were recorded with a resolution set to 17,500 , with exclusion from MS/MS fragmentation of the parent ion for $15 \mathrm{~s}$. The equipment was externally calibrated according to the supplier's instructions. All samples were analysed in triplicate.

\section{Identification of peptides}

Peptides were identified from the MS/MS spectra using X!Tandem pipeline software (Plateforme d'Analyse Protéomique de Paris Sud-Ouest (PAPPSO), INRAE, Jouy-en-Josas, France, http://pappso.inra.fr). The search was performed against a database composed of reviewed proteins of Gallus gallus (2262 proteins downloaded to which was added the common Repository of adventitious Protein, http://thegpm.org/crap). Database search parameters were specified as follows: non-specific enzyme cleavage; a 0.05 Da mass error for fragment ions; $10 \mathrm{ppm}$ mass error for parent ions; with methionine oxidation and serine phosphorylation as putative modifications. A minimum score corresponding to an e-value below 0.05 was required for valid peptide identification.

\section{Prediction of antimicrobial activity of peptides}

According to an approach previously described by Bishop et al. ${ }^{15}$, the peptide sequences identified in the EW fractions were submitted to the free web-based ADAM database ${ }^{16}$ using SVM Predict 

SVM, Random Forest (RF), Artificial Neural Network (ANN) and Discriminant Analysis (DA) (http://www.camp.bicnirrh.res.in/predict/hii.php). Several physicochemical characteristics of these peptides were also calculated using ProtParam tools (ExPASy Bioinformatics Resource Portal): theoretical molecular weight, theoretical pI, hydrophobicity evaluated by the GRAVY index (Grand Average Hydropathy value) and stability evaluated by the Instability index. The net charge at $\mathrm{pH} 7.0$ and $\mathrm{pH} 9.0$ was predicted using the Protein Calculator v3.4 (https://protcalc.sourceforge.net/cgi-bin/protcalc). Comments about structure features were extracted from the Antimicrobial Peptide Calculator and Predictor APD3 (http://aps.unmc.edu/AP/prediction/actionInput.php).

\section{Peptide synthesis}

The peptides P1=FVPPVQR, P2=GDPSAWSWGAEAHS, P3=TPPFGGFR, and

P4=HPFIQHPVHG were synthesized by Eurogentec (Angers, France) at purity rates above 95\%. Stock solutions were prepared by dissolving each synthetic peptide in sterile ultrapure water at $2 \mathrm{mg} / \mathrm{mL}$ and stored at $-20{ }^{\circ} \mathrm{C}$ until use.

\section{Anti-Salmonella activity measurement}

The anti-Salmonella activity of EW, EWFs and isolated EW peptides was determined by incubation with Salmonella for $24 \mathrm{~h}$ at 45 and $30{ }^{\circ} \mathrm{C}$ (as a control temperature), as follows. After overnight propagation in tryptone soy broth (TSB, pH 7.3, Merck, Darmstadt, Germany), Salmonella cultures were centrifuged $\left(5,600 \mathrm{~g}\right.$ at $15^{\circ} \mathrm{C}$ for $\left.7 \mathrm{~min}\right)$ and cells were washed three times in the same volume of tryptone salt medium (AES, Combourg, France) or TSB (when TSB was used as the assay medium). The washed pellets were finally resuspended in the same 
(Starlab, Bagneux, France) containing $800 \mu \mathrm{L}$ of the assay medium to obtain a final Salmonella inoculum level of $6 \pm 0.2 \log _{10} \mathrm{CFU} / \mathrm{mL}$.

To test the antibacterial activity of the peptides of interest, assay medium with synthetic P1, P2, P3 or P4 peptides $(100 \mu \mathrm{g} / \mathrm{mL})$ in either $400 \mathrm{Da}$ EWF or minimal medium M63 $\left(\mathrm{KH}_{2} \mathrm{PO}_{4} 60\right.$ $\mathrm{mM},\left(\mathrm{NH}_{4}\right)_{2} \mathrm{SO}_{4} 1.5 \mathrm{mM}, \mathrm{MgSO}_{4} 1 \mathrm{mM}$, glucose $0.4 \%$ ) were used; $\mathrm{pH}$ was adjusted to 9.2 with $\mathrm{KOH} 30 \%$.

To test the effect of $\mathrm{pH}$ and nutritional deficiency, the $\mathrm{pH}$ of the 400Da EWF was adjusted to 9.2 with $2 \mathrm{M} \mathrm{NaOH}$, and glucose and $\mathrm{NH}_{4} \mathrm{Cl}$ were added to a final concentration of 25 and $3 \mathrm{mM}$, respectively.

After incubation for $24 \mathrm{~h}$ at $30^{\circ} \mathrm{C}$, viable cell numbers were determined using a numeration method based on the miniaturization of the conventional plate-counting technique, according to Baron et al. ${ }^{17}$ with a Tryptone soya agar (TSA) (Merck, Darmstadt, Germany) overlay procedure. Results were compared using analysis of variance and the average comparison test using the R 2.13.0 software (http://cran.r-project.org).

\section{Results and Discussion}

Removal of components $>400$ Da significantly reduces, but does not eliminate the bactericidal activity of EW against $S$. Enteritidis at $45^{\circ} \mathrm{C}$

The approach adopted to investigate the key factors responsible for the bactericidal effect of EW and EWFs on $S$. Enteritidis at $45^{\circ} \mathrm{C}$ was based on an EW fractionation strategy using successive ultrafiltration and nanofiltration steps (10 kDa, $1 \mathrm{kDa}$ and $400 \mathrm{Da}$ cut-off, respectively) followed by assessment of $S$. Enteritidis survival at $45^{\circ} \mathrm{C}$ (and $30{ }^{\circ} \mathrm{C}$ as a control) in EW and in the three resulting fractions: 10kDa EWF, 1kDa EWF, and 400DaEWF.

A strong bactericidal effect was observed after $24 \mathrm{~h}$ at $45{ }^{\circ} \mathrm{C}$ in all EW fractions: Salmonella cells were undetectable in EW, $10 \mathrm{kDa}$ EWF and $1 \mathrm{kDa}$ EWF which corresponds to a $6 \log _{10}$ reduction in cell numbers. However, $S$. Enteritidis only decreased by $2.6 \pm 0.5 \log _{10}$ in the $400 \mathrm{Da}$ 
EWF (Figure 2A). The bactericidal effect observed was not simply due to temperature as there was an increase of $2.6 \pm 0.2 \log _{10} \mathrm{CFU} / \mathrm{mL}$ after $24 \mathrm{~h}$ when incubation at $45{ }^{\circ} \mathrm{C}$ was performed in TSB rather than EW or the EWFs. However, the bactericidal effect was only observed for EW and EWFs at $45{ }^{\circ} \mathrm{C}$; at $30{ }^{\circ} \mathrm{C}$ the Salmonella cells count increased in all the media tested (Figure 2B). Nevertheless, the growth at $30{ }^{\circ} \mathrm{C}$ was significantly lower in EW and in EWFs $\left(+1.5 \pm 0.7 \log _{10} \mathrm{CFU} / \mathrm{mL}\right.$ in $\mathrm{EW} ;+2.4 \pm 0.2 \log _{10} \mathrm{CFU} / \mathrm{mL}$ in $10 \mathrm{kDa}$ and $1 \mathrm{kDa} \mathrm{EWF}$, and $+1.1 \pm 0.2 \log _{10} \mathrm{CFU} / \mathrm{mL}$ in $400 \mathrm{Da}$ EWF $)$ than in TSB medium $\left(+3.4 \pm 0.1 \log _{10} \mathrm{CFU} / \mathrm{mL}\right)$. The above results are in agreement with those previously obtained in EW and $10 \mathrm{kDa} E W F$ at $30{ }^{\circ} \mathrm{C}^{2}$ and $45{ }^{\circ} \mathrm{C}^{10,14}$, and they indicate that EW and the EWFs allow significant growth of $S$. Enteritidis at $30^{\circ} \mathrm{C}$, but become strongly bactericidal at $45^{\circ} \mathrm{C}$, unlike standard growth medium. Importantly, the bactericidal activity towards $S$. Enteritidis at $45^{\circ} \mathrm{C}$ was significantly reduced for the 400Da EWF suggesting that EW factors larger than 400 Da play a major role in the bactericidal activity of EW at this temperature.

In order to confirm the differences in the bactericidal activity of the 400Da EWF and the other EW fractions, $S$. Enteritidis survival was measured at $45{ }^{\circ} \mathrm{C}$ (and $30{ }^{\circ} \mathrm{C}$ as a control) in the 400Da EWF with addition of the 400Da EWR at 0-100\% (v/v) concentration (Figure 3). A clear dose-dependent response was observed, with a progressive increase in bactericidal activity at $45^{\circ} \mathrm{C}$ achieved as the percentage of 400Da EWR was elevated, with the activity reaching a maximum $6 \log _{10}$ reduction with 100\% (v/v) 400Da EWR (Figure 3A), as was obtained for the $1 \mathrm{kDa}$ and $10 \mathrm{kDa}$ EWFs (Figure 2A). Addition of the 400Da EWR to the 400Da EWF also restored the growth of $S$. Enteritidis at $30{ }^{\circ} \mathrm{C}$ (Figure 3B), such that the same level of growth was seen as that obtained for the $1 \mathrm{kDa}$ or $10 \mathrm{kDa}$ EWFs (Figure $2 \mathrm{~B}$ ). This indicates that the 400Da EWR provides a source of nutrients for $S$. Enteritidis growth at $30^{\circ} \mathrm{C}$, but contributes to the antibacterial activity observed at $45^{\circ} \mathrm{C}$. In summary, the above data indicate that the bactericidal components of EW can be separated into two fractions on the basis of mass (> and 
$<400 \mathrm{Da}$ ), and that recombining these fractions restores the bactericidal activity obtained at $45^{\circ} \mathrm{C}$ to match that seen for whole EW. The results therefore supports that the bactericidal activity of EW at $45{ }^{\circ} \mathrm{C}$ is a multifactorial phenomenon ${ }^{1}$, and suggests it may result from the combination of physicochemical factors, and small molecules $(<10 \mathrm{kDa}$ and $>400 \mathrm{Da})$ such as antimicrobial peptides.

\section{Contribution of physicochemical factors to the bactericidal activity of $\mathrm{EW}$ at $45{ }^{\circ} \mathrm{C}$}

Chemical analysis of EW, and the 10kDa and 400Da EWFs was performed (Table 1) to determine whether there are any differences that could explain the reduced bactericidal activity seen for the 400Da EWF. The glucose (180 Da) concentration in EW and 10kDa EWF (21 and $25 \mathrm{mM}$, respectively) was approximately twofold higher than that typically used in culture media (around $11 \mathrm{mM}$ glucose); a similar glucose concentration (17 mM) was also measured in $1 \mathrm{kDa}$ EWF (data not shown). This suggests that there is sufficient glucose in EW but also in $10 \mathrm{kDa}$ EWF and 1kDa EWF to support $S$. Enteritidis growth. However, it is possible that the 4 to 5-fold lower level of glucose $(4.8 \mathrm{mM})$ in the 400Da EWF might contribute to the lower growth observed at $30{ }^{\circ} \mathrm{C}$ in $400 \mathrm{Da} \mathrm{EWF}$ in comparison to $10 \mathrm{kDa} \mathrm{EWF}(+1.1 \pm 0.2 \log 10$ $\mathrm{CFU} / \mathrm{mL}$ and $+2.4 \pm 0.2 \log 10 \mathrm{CFU} / \mathrm{mL}$, respectively). However, it is unlikely that this difference in glucose content is responsible for the reduced bactericidal activity of the 400Da EWF at $45^{\circ} \mathrm{C}$.

The total nitrogen concentration was much higher in EW $(1364 \mathrm{mM})$ than in the $10 \mathrm{kDa}$ and 400Da EWFs (2.3 and 0.69 mM, respectively), which is consistent with the high level of protein (around 10\% w/v) in EW and the loss of protein from the EWFs through filtration (Table 1); the nitrogen content in $1 \mathrm{kDa} \mathrm{EWF}(2.1 \mathrm{mM})$ was similar to that measured in $10 \mathrm{kDa} E W F$ (data not shown). The low nitrogen concentration of 400Da EWF is close to the threshold concentration $(1 \mathrm{mM})$ for enterobacteria growth ${ }^{18}$. As for glucose, this relatively low nitrogen 
availability could contribute to the lower growth of $S$. Enteritidis at $30{ }^{\circ} \mathrm{C}$ in the 400Da EWF compared to $10 \mathrm{kDa}$ EWF, as suggested by Figure 4 . However, it is unlikely that this low protein content is responsible for the reduced bactericidal activity of $400 \mathrm{Da} \mathrm{EWF}$ at $45{ }^{\circ} \mathrm{C}$. As for the lower growth at $30^{\circ} \mathrm{C}$ in $\mathrm{EW}$ in comparison to $10 \mathrm{kDa} \mathrm{EWF}$ and $1 \mathrm{kDa} \mathrm{EWF}$, it was likely due to the presence of antimicrobial proteins in $\mathrm{EW}^{4}$.

For the eight major minerals presented in Table 1, some differences were found between EW and the EWFs. In particular, there were major decreases in iron and manganese, and modest decreases for zinc, copper, calcium, potassium and magnesium in the EWFs compared to EW (7.5-900, 250-500, 5-36, 3-9, 5-12, 0.98-1.25, 1.11-4 fold, respectively; Table 1). However, except for iron, the measured mineral concentrations are above the concentration thresholds considered necessary for bacterial growth ${ }^{19-24}$. EW is well recognized as an iron-deficient medium and it is generally considered that in whole EW iron is almost entirely bound to ovotransferrin $^{4}$ which would be lost upon filtration; this explains why the $10 \mathrm{kDa}$ and $400 \mathrm{Da}$ EWFs (both ovotransferrin-free) contain up to 900-fold less iron than EW. The reduced $\mathrm{Zn}, \mathrm{Cu}$ and (particularly) Mn in the EWFs suggest that these metals are also retained; this is likely to be due to association with EW macromolecules ${ }^{25}$. However, such reductions in mineral levels are unlikely to explain the reduced bactericidal activity of the 400Da EWF toward $S$. Enteritidis at $45^{\circ} \mathrm{C}$ (or reduced growth seen in $400 \mathrm{Da}$ EWF at $30^{\circ} \mathrm{C}$ ) since levels of these minerals are similar in the 10kDa and 400Da EWFs (Table 1).

One last difference between the 400Da EWF, and EW and the 10kDa EWF, is $\mathrm{pH}$ which was lower in the 400Da EWF (Table 1). The importance of alkaline $\mathrm{pH}$ for the antimicrobial activity is well reported ${ }^{1,6}$. Therefore, it is reasonable to suggest that the lower $\mathrm{pH}$ measured in the 400Da EWF could partly explain the lower bactericidal activity of this fraction compared to EW and 10kDa EWF. From all the physicochemical characteristics of 400Da EWF determined here, its $\mathrm{pH}(8.7)$ is the most likely hypothesis to explain the least bacteria destruction observed 
at $45{ }^{\circ} \mathrm{C}$ in this medium in comparison with $10 \mathrm{kDa}$ EWF. To test whether the reduced $\mathrm{pH}$, glucose or nitrogen concentrations of the 400Da EWF compared to EW and 10kDa EWF could account for its reduced bactericidal activity, Salmonella survival was measured in the 400Da EWF at $45^{\circ} \mathrm{C}$ (and $30{ }^{\circ} \mathrm{C}$ as control) at $\mathrm{pH} 8.7$ and 9.2, with glucose at $25 \mathrm{mM}$ and nitrogen at $3 \mathrm{mM}$ (final concentrations) (Figure 4). The modifications of 400Da EWF did not significantly change ( $>>0.05$ ) bactericidal activity at $45{ }^{\circ} \mathrm{C}$ (Figure 4A), indicating that the changes in $\mathrm{pH}$, glucose and nitrogen availability are not responsible for the reduced bactericidal activity of the 400Da EWF compared to the 10kDa EWF. However, the combined increase in $\mathrm{pH}$, nitrogen and glucose content of the 400Da EWF did result in a significant increase in $S$. Enteritidis growth at $30{ }^{\circ} \mathrm{C}$, although growth was still lower than that obtained in 10kDa EWF (Figure 4B). These findings indicate that nutrient (carbon and/or nitrogen sources) availability and $\mathrm{pH}$ are factors that impact $S$. Enteritidis growth in $\mathrm{EW}$ at $30^{\circ} \mathrm{C}$. Since adjusting $\mathrm{pH}$, glucose and nitrogen availability only partly restored growth in $400 \mathrm{Da} \mathrm{EWF}$ at $30{ }^{\circ} \mathrm{C}$ towards that seen in the $10 \mathrm{kDa} \mathrm{EWF}$, it is likely that there are other differences between these filtrates that affect growth. As the iron, zinc, copper and manganese levels are similar in the 400Da EWF and the $10 \mathrm{kDa} \mathrm{EWF}$, it is unlikely that differences in availability of these metals would explain the difference in growth. So other factors are likely responsible for this effect.

\section{Putative antimicrobial peptides (AMPs) are present in EW ultrafiltrates}

To test the possible involvement of small bioactive compounds in the bactericidal activity of EW and EWFs at $45^{\circ} \mathrm{C}$, the $10 \mathrm{kDa}$ and 400Da EWFs, and 400Da EWR were analysed by mass spectrometry (MS). No peptides could be detected in the 400Da EWF, consistently with the very low nitrogen content measured in this fraction (equivalent to a peptide content of $0.06 \mathrm{~g} / \mathrm{L}$ ) but 12 peptides were identified in the $10 \mathrm{kDa} E W F$, the peptide content of which was estimated at $0.2 \mathrm{~g} / \mathrm{L}$. All 12 peptides were also detected in the 400Da EWR in addition with 10 other peptides (Table 2). The higher number of peptides detected in the 400Da EWR likely results 
from a higher concentration in the retentate (peptide content estimated at $0.44 \mathrm{~g} / \mathrm{L}$ ) with respect to that in the more diluted 10kDa EWF. However, due to the detection threshold of LC-MS/MS analysis, it is likely that other peptides present at very low concentration might exist in EWFs. Similarly, because of technical limits which make impossible the identification of peptides smaller than 5 to 6 amino acid residues and those larger than 40 to 45 amino acid residues, the list of peptides detected in 10kDa EWF and 400Da EWR is likely not exhaustive. In particular, it is noteworthy that avian beta-defensin 11 (AvBD11; 82 amino acid residues), gallin (OvoDA1; 41 amino acid residues) and OvoDB1 (45 amino acid residues), all previously identified in EW, were not detected in the present study ${ }^{4,26,27}$.

The peptides identified originate mainly from ovocleidin-116 and clusterin, two minor proteins previously identified in $\mathrm{EW}^{28,29}$ (Table 2). Ovocleidin-116 is a major component of the eggshell matrix, and a main actor of the regulation of eggshell calcification ${ }^{30}$. Hen egg clusterin is a structural component of the eggshell matrix, but also identified in $\mathrm{EW}^{31}$; clusterins are ubiquitous proteins with molecular chaperone function ${ }^{32}$. Among the 11 peptides stemming from clusterin, four belong to the fragment [203-221: TPPFGGFREAFVPPVQRVR] (group 3, Table 2), five to the fragment [211-221: EAFVPPVQRVR] (group 1, Table 2), and two to the fragment [232-246: EIHPFIQHPVHGFHR] (group 4, Table 2). Among the nine peptides derived from ovocleidin-116 (group 5, Table 2), two belong to the fragment [459-482: VQQEVAPARGVVGGMVVPEGHRAR], six to the fragment [561-587: IGQAARPEVAPAPSTGGRIVAPGGHRA], and one corresponds to the fragment [622-643: STDVPRDPWVWGSAHPQAQHTR]). Moreover, two peptides originate from zona pellucida sperm binding protein 3, called ZP3. ZP3 is one of the five ZPs present in the vitelline membrane of bird eggs, all playing an important role in egg fertilization. ZP3 is especially involved in the binding of sperm in the germinal disc region of the yolk ${ }^{33,34}$. Both peptides stemming from this protein and identified in 400Da EWR belong to the fragment [86-99: 
GDPSAWSWGAEAHS] (group 2, Table 2). To the best of our knowledge, no antibacterial activity has been ever reported for ovocleidin-116, hen egg clusterin, and ZP3.

The main physicochemical properties of the peptides are summarized in Table 2. Their molecular weight ranges from 722 to $2,528 \mathrm{Da}$, and their predicted $\mathrm{pI}$ from 3.39 to 11.8. A high proportion of these peptides (16 out of 22) are likely to form an $\alpha$-helix. Moreover, most (17 out of 22) are predicted to be positively charged at neutral $\mathrm{pH}$, and 13 are predicted to remain positively charged at $\mathrm{pH} 9$ (close to the $\mathrm{pH}$ of 9.3 used in the present study, that is the natural EW $\mathrm{pH}$ a few days after laying). A positive net charge and helicity are well known characteristics of $\mathrm{AMPs}^{35}$. To further probe the potential antibacterial activity of the peptides identified, a bioinformatics approach was applied.

All the peptide sequences identified were evaluated for their potential antimicrobial activity using web-based prediction tools in the ADAM and cAMP-databases (see M\&M section). Nine peptides presented a negative ADAM score and were not considered for further analysis. All nine of these peptides stemmed from ovocleidin-116 (group 5, Table 2). In contrast, 13 peptides achieved a positive ADAM score ranging from 0.61 to 2.31 . These 13 peptides can be divided into four groups, based on the shortest common sequence (Table 2). As a complement to this analysis based on the ADAM database, the cAMP prediction scores were calculated for these 13 peptides, using four different algorithms. To enable experimental determination of the antimicrobial activity of representative peptides from the set identified, four peptides were selected for synthesis on the basis of the following criteria: i) the peptide showing the highest ADAM score within each of the 4 groups (1-4) of relevance (Table 1); and ii) possessing at least one positive cAMP database score. Thus, four peptides (designated P1, P2, P3 and P4 in Table 2) were selected.

With a GRAVY index score above zero, $\mathrm{P} 3$ is considered a hydrophobic peptide, whereas P2 and P4 are mostly hydrophilic; P1 has a predicted intermediary hydrophobic/hydrophilic nature 
(Table 2). Moreover, out of the four potential AMPs selected, P2 is the only one likely to form a $\alpha$-helix, whereas P1 and P3 are rich in proline residues, well-known for their "helix-breaker" effect $^{36}$. P1 and P3 are also predicted to be structurally unstable, based on Instability Index, whereas $\mathrm{P} 2$ and $\mathrm{P} 4$ are predicted as stable (Table 2).

Two out of the four putative EW AMPs selected exert a bactericidal activity against $S$. Enteritidis at $45{ }^{\circ} \mathrm{C}$

To experimentally determine the antimicrobial activity of the four selected predicted AMPs, $S$. Enteritidis survival was assessed at $45{ }^{\circ} \mathrm{C}$ (and $30{ }^{\circ} \mathrm{C}$ for control) in 400Da EWF with chemically synthesized P1, P2, P3 or P4 peptides, and the bacterial enumeration was compared to that obtained in 10kDa EWF, 400Da EWF and TSB (Figure 5).

None of the four peptides tested displayed antibacterial activity at $30{ }^{\circ} \mathrm{C}$ (Figure 5B). Additionally, the P3 and P4 peptides had no effect on the bactericidal activity of 400Da EWF at $45^{\circ} \mathrm{C}$ (Figure 5A). In contrast, the $\mathrm{P} 1$ and $\mathrm{P} 2$ peptides (at $100 \mu \mathrm{g} / \mathrm{mL} ; 119$ and $69 \mu \mathrm{M}$ for $\mathrm{P} 1$ and $\mathrm{P} 2$, respectively) strongly increased $(\mathrm{p}<0.001)$ the bactericidal activity of 400Da EWF at $45^{\circ} \mathrm{C}$. Indeed, the addition of either P1 or P2 resulted in a substantial $6 \log _{10}$ reduction of $S$. Enteritidis that is the same bactericidal effect than that observed for $10 \mathrm{kDa}$ EWF at $45{ }^{\circ} \mathrm{C}$ (Figure 5A). Therefore, the results suggest that $\mathrm{P} 1$ and $\mathrm{P} 2$ contribute to the bactericidal activity of EW and EW ultrafiltrates at $45^{\circ} \mathrm{C}$. The effect of concentration on the bactericidal activities of P1 and P2 was also tested, and the results show a dose-dependent response for both peptides at $45{ }^{\circ} \mathrm{C}$ in $400 \mathrm{Da}$ EWF over a concentration range from 0 to $100 \mu \mathrm{g} / \mathrm{mL}$, with a higher bactericidal effect for P2 (Figure 6B) than for P1 (Figure 6A).

Thus, the P1 and P2 peptides can be classified as bactericidal peptides active against $S$. Enteritidis under the specific conditions of EW or EW ultrafiltrates at $45{ }^{\circ} \mathrm{C}$. Since $45{ }^{\circ} \mathrm{C}$ is close to the body temperature of the hen, $\mathrm{P} 1$ and $\mathrm{P} 2$ are likely to play a role in resisting 
S. Enteritidis infection during egg formation. However, the P1 and P2 peptides displayed no bactericidal activity in M63 minimal medium, even at $45^{\circ} \mathrm{C}$, either at $\mathrm{pH} 7.8$ or 9.2 (Figure 7). Then, P1 and P2 peptides cannot explain by themselves the bactericidal activity of EW and EW ultrafiltrates at $45^{\circ} \mathrm{C}$. Actually, it is very likely that both peptides interact in EW, as well as in $10 \mathrm{kDa}$ and $1 \mathrm{kDa}$ EWFs, with other harmful factors such as nutrient deprivation, alkaline $\mathrm{pH}$, or other unknown antimicrobial compounds.

To test any synergistic action for the $\mathrm{P} 1$ and $\mathrm{P} 2$ peptides, the bactericidal effect of combining the two peptides in $400 \mathrm{Da} \mathrm{EWF}$ at $45^{\circ} \mathrm{C}$ was examined (Figure 8). The results show a clear synergistic effect for a 1:1 w/w combination of P1 and P2 $(25 \mu \mathrm{g} / \mathrm{mL}$ total concentration) with a higher bactericidal activity compared to that obtained for each peptide alone at the same concentration (Figure 8). A $6 \log _{10}$ reduction of $S$. Enteritidis was obtained after $24 \mathrm{~h}$ incubation with the peptide mixture, whereas only $2.55 \pm 0.48$ and $4.5 \pm 0.15 \log _{10}$ reductions were obtained with P1 and P2 alone, respectively (Figure 8). Combining P1 and P2 had no apparent effect on S. Enteritidis growth in 400Da EWF at $30{ }^{\circ} \mathrm{C}$ compared to that observed in the absence of peptides (data not shown).

To conclude, this study has advanced understanding of the bactericidal activity of EW at $45^{\circ} \mathrm{C}$. In particular, two new AMPs (P1 and P2) have been identified in EW and their likely involvement in the bactericidal activity of EW has been revealed. The P1 and P2 peptides have characteristics commonly attributed to AMPs. These characteristics include a total hydrophobic ratio (defined using the APD tool: http://aps.unmc.edu/AP/ ${ }^{37}$ ) of $42 \%$ and $35 \%$ for $\mathrm{P} 1$ and $\mathrm{P} 2$, respectively, which matches the relatively high proportion ( $\geq 30 \%$ or more) of hydrophobic residues often associated with $\mathrm{AMPs}^{35}$. Moreover, P1 contains two Pro residues (28\% of all residues) and one Arg residue (14\%), whereas P2 contains two Trp (14\%), one Pro (7\%) and one His $(7 \%)$ residues, which are common features of AMPs ${ }^{35,37}$. Furthermore, according to the APD tool for structure prediction, P2 may form a $\alpha$-helix with at least three residues on the 
same hydrophobic surface, suggesting an amphiphilic helix folding pattern, as hypothesized for AMPs such as magainins or cecropins; this property is thought to promote interaction with the bacterial membrane ${ }^{35,38}$. Lastly, P1 has $43 \%$ similarity to an AMP registered in the APD database under ID AP02431 (TPPQS), which originates from Bacillus subtilis ${ }^{39}$, while P2 has 43\% similarity to another AMP registered under ID AP02938 (GTAWRWHYRARS), obtained from the rumen microbiome ${ }^{40}$. P1 has a predicted alkaline $\mathrm{pI}(\mathrm{pI}=9.75)$ and thus would be very slightly cationic at $\mathrm{pH} 9$ (i.e. close to the $\mathrm{pH}$ here tested), while $\mathrm{P} 2$ is an acidic peptide ( $\mathrm{pI}=4.35$ ). Thus, under the conditions tested here, neither $\mathrm{P} 1$ nor $\mathrm{P} 2$ have the strong cationic characteristics widely reported for AMPs, and regarded as critical for interaction between AMPs and bacterial membranes, which is considered to be the first step leading to AMP-mediated membrane dysfunction and disruption ${ }^{35}$. Nonetheless, some anionic or non-cationic peptides are proven $\mathrm{AMPs}^{38}$, suggesting that a cationic characteristic is not a strict requirement for AMP functionality. In any case, it is likely that P1 and P2 do not act like typical AMPs, since their most striking feature is that their activity requires both a permissible temperature $\left(45^{\circ} \mathrm{C}\right)$ and a specific medium composition (EW or EWF).

Despite the original features of P1 and P2 in comparison to most of AMPs, the assumption of membrane disruption induced by these peptides is preferred. Indeed, a previous study evidenced membrane damage (inner and outer membranes) on E. coli during incubation in same conditions, i.e. in $\mathrm{EW}$ at $45^{\circ} \mathrm{C}^{41}$. Moreover, the influence of temperature on $\mathrm{P} 1$ and $\mathrm{P} 2$ bactericidal activity could be related to membrane fluidity as high temperatures increase the fluidization of biological membranes ${ }^{42}$. Then, the ability of antimicrobial components to cross and/or disrupt the bacterial membrane increases as membrane fluidity rises. The mechanism governing the observed synergy between $\mathrm{P} 1$ and $\mathrm{P} 2$ is unclear, but this finding highlights the potential for synergistic action of antimicrobial components in EW. 
Finally, this study confirms the antibacterial role of the EW peptide fraction, besides that of antibacterial proteins described for a long time ${ }^{4}$. It is especially significant as few is known about the antibacterial peptides naturally present in EW. Despite a great number of peptides have been identified in EW during the last decades thanks to proteomics, the biological functions of most of them, and especially their antimicrobial activities have still to be investigated ${ }^{4}$. To date, an avian- $\beta$-defensin and a gallin have been identified in hen $\mathrm{EW}^{43}$ and their antibacterial activities have been confirmed ${ }^{26,44}$. These natural peptides both belong to the family of defensins which are part of the innate immune system in many living species. Avian$\beta$-defensins are cationic peptides of 1 to $9 \mathrm{kDa}$ identified in the eggs of several bird species ${ }^{45}$. These peptides are expressed in many different tissues, including the hen oviduct ${ }^{46}$, which explains that the different compartments of hen egg contain avian- $\beta$-defensins which are supposed to be involved in the protection of the embryo during hatching ${ }^{26}$. Ovodefensins, a sub-family of $\beta$-defensins including gallin (4732 Da), have been also identified in the EW of different bird species ${ }^{4}$. Moreover, it is more than likely that EW contain many other antimicrobial peptides, not yet identified, as indicated by the consequence of EW treatment with proteinase $\mathrm{K}$. This treatment eradicated the anti-Salmonella activity of a $3 \mathrm{kDa} \mathrm{EWF}$, suggesting that antimicrobial polypeptides smaller than $3 \mathrm{kDa}$ play an active role in the antibacterial defence of $\mathrm{EW}^{47}$. However, what does differ between both peptides identified in the present study and antimicrobial peptides such as defensins, is that P1 and P2 are not expressed as such from the hen genome, but are stemming from larger proteins, namely 427 clusterin and ZP3, respectively. This consequently indicate that these proteins have been hydrolysed in situ. It is noteworthy that in quail eggs, a 26 amino acid sequence containing a homologous sequence of P2 peptide was removed from ZP3 after ovulation, presumably by a protease secreted in the infundibulum ${ }^{48}$. This might explain why $\mathrm{P} 2$ peptide which stems from a vitelline membrane protein (ZP3) was found in EW. It could be hypothesized that this peptide, 
released from the vitelline membrane into the forming EW after ovulation, could play a role in protecting the embryo during the completion of egg formation in the oviduct. The fact that P2 peptide specifically acts at $45^{\circ} \mathrm{C}$, close to the hen body temperature, supports this assumption. More generally speaking, protein degradation during formation and/or storage of eggs was previously reported, based on the decrease of the band intensity of some proteins in electrophoresis $^{49}$, and more recently, the release of small peptides $(<10 \mathrm{kDa}$ and $<3 \mathrm{kDa})$ was also established ${ }^{50}$. However, the mechanisms responsible for the proteolysis still remain unknown in most cases. Various proteases naturally present in $\mathrm{EW}^{51}$ could catalyse the proteolysis. Self-degradation of proteins has been also described as a spontaneous and quite universal phenomenon ${ }^{52}$. However, only small peptides stemming from ovotransferrin, ovomucin, ovomucoid and ovoinhibitor, i.e. major proteins, have been described in EW to date $^{50}$. In the present study, it is noteworthy that the EW fractionation strategy using ultra- and nanofiltration membranes, leading to a concentrated fraction (400Da EWR), enabled the access to peptides stemming from minor EW proteins. Then, whereas protein degradation can be seen as a potentially detrimental phenomenon when it concerns antimicrobial proteins (ovotransferrin, lysozyme, ovoinhibitor, ovomucoid), the present study highlights it could also contribute to a higher protection of eggs against bacteria, thanks to the release of antimicrobial peptides from non-antimicrobial proteins such as clusterins and ZP3. Beyond the specific issue of egg protection, this study also underlines that egg white proteins, even non-antimicrobial ones, should be considered as potential natural sources of antimicrobial peptides. This has special relevance where innovative antimicrobial molecules are being sought to counteract increasing bacterial resistance which is a major public health challenge.

\section{Corresponding author}


455

456

457

458

459

460

461

462

463

464

465

466

467

468

469

470

471

*(M-F.C.) Mailing address: Institut Agro, UMR STLO, 65 rue de St Brieuc, 35042 Rennes cedex, France. Phone: +33(0)223485575. E-mail: marie-francoise.cochet@agrocampus$\underline{\text { ouest.fr }}$

\section{Notes}

The authors declare no competing financial interest.

\section{Acknowledgements}

The authors thank Anne Dudley (Analytical Technical Services Division, University of Reading) for ICP-OES analysis.

\section{Funding sources}

This study was conducted without any external funding to be claimed.

\section{Abbreviations used}

EW, Egg White; EWR, Egg White Retentate; EWF, Egg White Filtrate; AMP, Antimicrobial Peptide; cAMP, Collection of Antimicrobial Peptides; SVM, Support Vector Machine; RF, Random Forest; ANN, Artificial Neural Network; DA, Discriminant Analysis; GRAVY, Grand Average Hydropathy Value; APD, Antimicrobial Peptide Database; Nano LC-MS/MS; Nanoscale Liquid Chromatography coupled to tandem mass spectrometry; ICP-OES, Inductively Coupled Plasma-Optical Emission Spectrometry. 


\section{References}

(1) Alabdeh, M.; Lechevalier, V.; Nau, F.; Gautier, M.; Cochet, M.-F.; Gonnet, F.; Jan, S.; Baron, F. Role of Incubation Conditions and Protein Fraction on the Antimicrobial Activity of Egg White against Salmonella Enteritidis and Escherichia Coli. J Food Protect 2011, 74, 24-31. https://doi.org/10.4315/0362-028x.jfp-10-157.

(2) Baron, F.; Gautier, M.; Brule, G. Factors Involved in the Inhibition of Growth of Salmonella Enteritidis in Liquid Egg White. J. Food Protect. 1997, 60, 1318-1323.

(3) Garibaldi, J. A. Role of Microbial Iron Transport Compounds in Bacterial Spoilage of Eggs. Appl. Microbiol. 1970, 20 (4), 558-560.

(4) Baron, F.; Nau, F.; Guérin-Dubiard, C.; Bonnassie, S.; Gautier, M.; Andrews, S. C.; Jan, S. Egg White versus Salmonella Enteritidis! A Harsh Medium Meets a Resilient Pathogen. Food Microbiol. 2016, 53, Part B, 82-93. https://doi.org/10.1016/j.fm.2015.09.009.

(5) Hald, T.; Baggesen, D. L. EFSA BIOHAZ Panel (EFSA Panel on Biological Hazards), 2014. Scientific Opinion on the Public Health Risks of Table Eggs Due to Deterioration and Development of Pathogens; Europen Food Safety Authority, 2014.

(6) Kang, H.; Loui, C.; Clavijo, R. I.; Riley, L. W.; Lu, S. Survival Characteristics of Salmonella Enterica Serovar Enteritidis in Chicken Egg Albumen. Epidemiol Infect 2006, 134 (05), 967. https://doi.org/10.1017/S0950268806006054.

(7) Gantois, I.; Eeckhaut, V.; Pasmans, F.; Haesebrouck, F.; Ducatelle, R.; Immerseel, F. V. A Comparative Study on the Pathogenesis of Egg Contamination by Different Serotypes of Salmonella. Avian Pathology 2008, 37 (4), 399-406. https://doi.org/10.1080/03079450802216611.

(8) Lu, S. W.; Killoran, P. B.; Riley, L. W. Association of Salmonella Enterica Serovar Enteritidis YafD with Resistance to Chicken Egg Albumen. Infect. Immun. 2003, 71, 6734-6741. https://doi.org/10.1128/iai.71.12.6734-6741.2003.

(9) Růzicková, V. Growth and Survival of Salmonella Enteritidis in Selected Egg Foods. Vet Med (Praha) 1994, 39 (4), 187-195.

(10) Baron, F.; Bonnassie, S.; Alabdeh, M.; Cochet, M.-F.; Nau, F.; Guérin-Dubiard, C.; Gautier, M.; Andrews, S. C.; Jan, S. Global Gene-Expression Analysis of the Response of Salmonella Enteritidis to Egg White Exposure Reveals Multiple Egg White-Imposed Stress Responses. Front Microbiol 2017, 8. https://doi.org/10.3389/fmicb.2017.00829.

(11) Raspoet, R.; Shearer, N.; Appia-Ayme, C.; Haesebrouck, F.; Ducatelle, R.; Thompson, A.; Immerseel, F. V. A Genome-Wide Screen Identifies Salmonella Enteritidis Lipopolysaccharide Biosynthesis and the HtrA Heat Shock Protein as Crucial Factors Involved in Egg White Persistence at Chicken Body Temperature. Poultry Science 2014, 93 (5), 1263-1269. https://doi.org/10.3382/ps.2013-03711.

(12) De Vylder, J.; Raspoet, R.; Dewulf, J.; Haesebrouck, F.; Ducatelle, R.; Van Immerseel, F. Salmonella Enteritidis Is Superior in Egg White Survival Compared with Other Salmonella Serotypes. Poult Sci 2013, 92 (3), 842-845. https://doi.org/10.3382/ps.201202668.

(13) Liot, R.; Anza, L. Procédé de Traitement de Blanc d'oeuf Liquide. 9608356, July 4, 1996.

(14) Baron, F.; Cochet, M.-F.; Alabdeh, M.; Guérin-Dubiard, C.; Gautier, M.; Nau, F.; Andrews, S. C.; Bonnassie, S.; Jan, S. Egg-White Proteins Have a Minor Impact on the Bactericidal Action of Egg White towards Salmonella Enteritidis at $45^{\circ} \mathrm{C}$. Front. Microbiol. 2020, 11. https://doi.org/10.3389/fmicb.2020.584986.

(15) Bishop, B. M.; Juba, M. L.; Devine, M. C.; Barksdale, S. M.; Rodriguez, C. A.; Chung, M. C.; Russo, P. S.; Vliet, K. A.; Schnur, J. M.; van Hoek, M. L. Bioprospecting the 
American Alligator (Alligator Mississippiensis) Host Defense Peptidome. PLoS ONE 2015, 10 (2), e0117394. https://doi.org/10.1371/journal.pone.0117394.

(16) Lee, H.-T.; Lee, C.-C.; Yang, J.-R.; Lai, J. Z. C.; Chang, K. Y. A Large-Scale Structural Classification of Antimicrobial Peptides https://www.hindawi.com/journals/bmri/2015/475062/ (accessed Apr 13, 2018). https://doi.org/10.1155/2015/475062.

(17) Baron, F.; Cochet, M. F.; Ablain, W.; Grosset, N.; Madec, M. N.; Gonnet, F.; Jan, S.; Gautier, M. Rapid and Cost-Effective Method for Microorganism Enumeration Based on Miniaturization of the Conventional Plate-Counting Technique. Lait 2006, 86, 251-257. https://doi.org/10.1051/lait:2006005.

(18) Magasanik, B. Regulation of Nitrogen Assimilation. In Regulation of Gene Expression in Escherichia coli; Lin, E. C. C., Lynch, A. S., Eds.; Springer US: Boston, MA, 1996; pp 281-290. https://doi.org/10.1007/978-1-4684-8601-8_13.

(19) Ploeg, J. R. van der; Iwanicka-Nowicka, R.; Kertesz, M. A.; Leisinger, T.; Hryniewicz, M. M. Involvement of CysB and Cbl Regulatory Proteins in Expression of the tauABCD Operon and Other Sulfate Starvation-Inducible Genes in Escherichia Coli. Journal of Bacteriology 1997, 179 (24), 7671-7678. https://doi.org/10.1128/jb.179.24.76717678.1997.

(20) Schramke, H.; Laermann, V.; Tegetmeyer, H. E.; Brachmann, A.; Jung, K.; Altendorf, K. Revisiting Regulation of Potassium Homeostasis in Escherichia Coli: The Connection to Phosphate Limitation. MicrobiologyOpen 2017, 6 (3), e00438. https://doi.org/10.1002/mbo3.438.

(21) Andrews, S. C.; Robinson, A. K.; Rodriguez-Quinones, F. Bacterial Iron Homeostasis. FEMS Microbiol Rev 2003, 27, 215-237. https://doi.org/10.1016/s0168-6445(03)00055$\mathrm{x}$.

(22) Pontes, M. H.; Groisman, E. A. Protein Synthesis Controls Phosphate Homeostasis. Genes Dev. 2018, 32 (1), 79-92. https://doi.org/10.1101/gad.309245.117.

(23) Anjem, A.; Varghese, S.; Imlay, J. A. Manganese Import Is a Key Element of the OxyR Response to Hydrogen Peroxide in Escherichia Coli. Molecular Microbiology 2009, 72 (4), 844-858. https://doi.org/10.1111/j.1365-2958.2009.06699.x.

(24) Outten, C. E.; O'Halloran, and T. V. Femtomolar Sensitivity of Metalloregulatory Proteins Controlling Zinc Homeostasis. Science 2001, 292 (5526), 2488-2492. https://doi.org/10.1126/science.1060331.

(25) Tan, A. T.; Woodworth, R. C. Ultraviolet Difference Spectral Studies of Conalbumin Complexes with Transition Metal Ions. Biochemistry 1969, 8 (9), 3711-3716. https://doi.org/10.1021/bi00837a033.

(26) Hervé-Grépinet, V.; Réhault-Godbert, S.; Labas, V.; Magallon, T.; Derache, C.; Lavergne, M.; Gautron, J.; Lalmanach, A.-C.; Nys, Y. Purification and Characterization of Avian $\beta$-Defensin 11, an Antimicrobial Peptide of the Hen Egg. Antimicrob. Agents Chemother. 2010, 54 (10), 4401-4409. https://doi.org/10.1128/AAC.00204-10.

(27) Gong, D.; Wilson, P. W.; Bain, M. M.; McDade, K.; Kalina, J.; Hervé-Grépinet, V.; Nys, Y.; Dunn, I. C. Gallin; an Antimicrobial Peptide Member of a New Avian Defensin Family, the Ovodefensins, Has Been Subject to Recent Gene Duplication. BMC Immunology 2010, 11 (1), 12. https://doi.org/10.1186/1471-2172-11-12.

(28) Hincke, M. T.; Nys, Y.; Gautron, J.; Mann, K.; Rodriguez-Navarro, A. B.; McKee, M. D. The Eggshell: Structure, Composition and Mineralization. Front Biosci (Landmark Ed) 2012, 17, 1266-1280.

(29) Reyes-Grajeda, J. P.; Moreno, A.; Romero, A. Crystal Structure of Ovocleidin-17, a Major Protein of the Calcified Gallus Gallus Eggshell. J. Biol. Chem. 2004, 279 (39), 40876-40881. https://doi.org/10.1074/jbc.M406033200. 
(30) Riou, C.; Cordeiro, L.-A.; Gérard, N. Eggshell Matrix Proteins OC-116, OC-17 and OCX36 in Hen's Sperm Storage Tubules. Animal Reproduction Science 2017, 185, np.

(31) Mann, K.; Gautron, J.; Nys, Y.; McKee, M. D.; Bajari, T.; Schneider, W. J.; Hincke, M. T. Disulfide-Linked Heterodimeric Clusterin Is a Component of the Chicken Eggshell Matrix and Egg White. Matrix Biology 2003, 22 (5), 397-407. https://doi.org/10.1016/S0945-053X(03)00072-6.

(32) Bertacchini, J.; Mediani, L.; Beretti, F.; Guida, M.; Ghalali, A.; Brugnoli, F.; Bertagnolo, V.; Petricoin, E.; Poti, F.; Arioli, J.; Anselmi, L.; Bari, A.; McCubrey, J.; Martelli, A. M.; Cocco, L.; Capitani, S.; Marmiroli, S. Clusterin Enhances AKT2-Mediated Motility of Normal and Cancer Prostate Cells through a PTEN and PHLPP1 Circuit. Journal of Cellular Physiology 2019, 234 (7), 11188-11199. https://doi.org/10.1002/jcp.27768.

(33) Nishio, S.; Kohno, Y.; Iwata, Y.; Arai, M.; Okumura, H.; Oshima, K.; Nadano, D.; Matsuda, T. Glycosylated Chicken ZP2 Accumulates in the Egg Coat of Immature Oocytes and Remains Localized to the Germinal Disc Region of Mature Eggs. Biol Reprod 2014, 91 (5). https://doi.org/10.1095/biolreprod.114.119826.

(34) Bausek, N.; Ruckenbauer, H. H.; Pfeifer, S.; Schneider, W. J.; Wohlrab, F. Interaction of Sperm with Purified Native Chicken ZP1 and ZPC Proteins. Biol Reprod 2004, 71 (2), 684-690. https://doi.org/10.1095/biolreprod.104.028605.

(35) Mahlapuu, M.; Håkansson, J.; Ringstad, L.; Björn, C. Antimicrobial Peptides: An Emerging Category of Therapeutic Agents. Front Cell Infect Microbiol 2016, 6. https://doi.org/10.3389/fcimb.2016.00194.

(36) Williamson, M. P. The Structure and Function of Proline-Rich Regions in Proteins. Biochemical Journal 1994, 297 (2), 249-260. https://doi.org/10.1042/bj2970249.

(37) Wang, G.; Li, X.; Wang, Z. APD3: The Antimicrobial Peptide Database as a Tool for Research and Education. Nucleic Acids Res. 2016, 44 (D1), D1087-1093. https://doi.org/10.1093/nar/gkv1278.

(38) Lei, J.; Sun, L.; Huang, S.; Zhu, C.; Li, P.; He, J.; Mackey, V.; Coy, D. H.; He, Q. The Antimicrobial Peptides and Their Potential Clinical Applications. Am J Transl Res 2019, 11 (7), 3919-3931.

(39) Ramachandran, R.; Chalasani, A. G.; Lal, R.; Roy, U. A Broad-Spectrum Antimicrobial

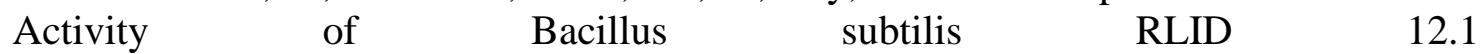
https://www.hindawi.com/journals/tswj/2014/968487/ (accessed Jun 2, 2020). https://doi.org/10.1155/2014/968487.

(40) Oyama, L. B.; Girdwood, S. E.; Cookson, A. R.; Fernandez-Fuentes, N.; Privé, F.; Vallin, H. E.; Wilkinson, T. J.; Golyshin, P. N.; Golyshina, O. V.; Mikut, R.; Hilpert, K.; Richards, J.; Wootton, M.; Edwards, J. E.; Maresca, M.; Perrier, J.; Lundy, F. T.; Luo, Y.; Zhou, M.; Hess, M.; Mantovani, H. C.; Creevey, C. J.; Huws, S. A. The Rumen Microbiome: An Underexplored Resource for Novel Antimicrobial Discovery. npj Biofilms and Microbiomes 2017, 3 (1), 1-9. https://doi.org/10.1038/s41522-017-0042-1.

(41) Jan, S.; Baron, F.; Alabdeh, M.; Chaari, W.; Grosset, N.; Cochet, M.-F.; Gautier, M.; Vié, V.; Nau, F. Biochemical and Micrographic Evidence of Escherichia Coli Membrane Damage during Incubation in Egg White under Bactericidal Conditions. $J$ Food Protect 2013, 76 (9), 1523-1529. https://doi.org/10.4315/0362-028X.JFP-12-418.

(42) Los, D. A.; Murata, N. Membrane Fluidity and Its Roles in the Perception of Environmental Signals. Biochimica et Biophysica Acta (BBA) - Biomembranes 2004, 1666 (1), 142-157. https://doi.org/10.1016/j.bbamem.2004.08.002.

(43) Mann, K. The Chicken Egg White Proteome. Proteomics 2007, 7 (19), 3558-3568. https://doi.org/10.1002/pmic.200700397.

(44) Whenham, N.; Lu, T. C.; Maidin, M. B. M.; Wilson, P. W.; Bain, M. M.; Stevenson, M. L.; Stevens, M. P.; Bedford, M. R.; Dunn, I. C. Ovodefensins, an Oviduct-Specific 
Antimicrobial Gene Family, Have Evolved in Birds and Reptiles to Protect the Egg by Both Sequence and Intra-Six-Cysteine Sequence Motif Spacing1. Biology of Reproduction 2015, 92 (6). https://doi.org/10.1095/biolreprod.114.126839.

(45) van Dijk, A.; Veldhuizen, E. J. A.; Haagsman, H. P. Avian Defensins. Vet Immunol Immunopathol 2008, 124 (1), 1-18. https://doi.org/10.1016/j.vetimm.2007.12.006.

(46) Mageed, A. M. A.; Isobe, N.; Yoshimura, Y. Expression of Avian Beta-Defensins in the Oviduct and Effects of Lipopolysaccharide on Their Expression in the Vagina of Hens. Poultry Science 2008, 87, 979-984. https://doi.org/10.3382/ps.2007-00283.

(47) Huang, X.; Hu, M.; Zhou, X.; Liu, Y.; Shi, C.; Shi, X. Role of YoaE Gene Regulated by CpxR in the Survival of Salmonella Enterica Serovar Enteritidis in Antibacterial Egg White. mSphere 2020, 5 (1). https://doi.org/10.1128/mSphere.00638-19.

(48) Pan, J.; Sasanami, T.; Nakajima, S.; Kido, S.; Doi, Y.; Mori, M. Characterization of Progressive Changes in ZPC of the Vitelline Membrane of Quail Oocyte Following Oviductal Transport. Molecular Reproduction and Development 2000, 55 (2), 175-181. https://doi.org/10.1002/(SICI)1098-2795(200002)55:2<175::AID-MRD6>3.0.CO;2-6.

(49) Guyot, N.; Labas, V.; Harichaux, G.; Chessé, M.; Poirier, J.-C.; Nys, Y.; RéhaultGodbert, S. Proteomic Analysis of Egg White Heparin-Binding Proteins: Towards the Identification of Natural Antibacterial Molecules. Scientific Reports 2016, 6 (1). https://doi.org/10.1038/srep27974.

(50) Liu, M.; Yu, W.; Ren, F.; Wu, J. Formation and Characterization of Peptides in Egg White during Storage at Ambient Temperature. Food Chemistry 2018, 263, 135-141. https://doi.org/10.1016/j.foodchem.2018.04.042.

(51) Mann, K.; Mann, M. In-Depth Analysis of the Chicken Egg White Proteome Using an LTQ Orbitrap Velos. Proteome Science 2011, 9 (1), 7. https://doi.org/10.1186/14775956-9-7.

(52) Sharma, M.; Luthra-Guptasarma, M. Degradation of Proteins upon Storage at NearNeutral PH: Indications of a Proteolytic/Gelatinolytic Activity Associated with Aggregates. Biochim. Biophys. Acta 2009, 1790 (10), 1282-1294. https://doi.org/10.1016/j.bbagen.2009.06.010.

(53) Nys, Y.; Sauveur, B. Valeur nutritionnelle des oeufs http://prodinra.inra.fr/?locale=fr\#!ConsultNotice:77361 (accessed Feb 17, 2016).

(54) Sauveur, B. Structure, Composition et Valeur Nutritionnelle de l'oeuf. In Reproduction des volailles et production d'oeufs; Lavoisier; Paris, 1988; pp 35-39.

(55) Nau, F.; Guérin-Dubiard, C.; Baron, F.; Thapon, J.-L. Science et technologie de l'oeuf production et qualité, Technique et Documentation.; Lavoisier; Vol. 1.

(56) Ciqual Table de composition nutritionnelle des aliments https://ciqual.anses.fr/ (accessed Jan 24, 2020).

(57) Egg Science and Technology; Stadelman, W. J., Cotterill, O. J., Eds.; Macmillan Education UK: London, 1986. https://doi.org/10.1007/978-1-349-09142-3. 
Table 1: Main physicochemical characteristics of 10kDa and 400Da egg white filtrates (EWF) and of egg white (EW) (*data from literature ${ }^{53-57}$ ).

\begin{tabular}{lccc}
\hline & EW & 10kDa EWF & 400Da EWF \\
\hline pH & 9.3 & 9.2 & 8.7 \\
glucose $(\mathbf{m M})$ & 25 & 21.5 & 4.8 \\
Total N (mM) & 1364 & 2.3 & 0.69 \\
Na $(\mathbf{m M})$ & 67.4 to $80.9^{*}$ & 96.1 & 62.7 \\
$\mathbf{K}(\mathbf{m M})$ & 35.8 to $44.2^{*}$ & 44.7 & 28.7 \\
$\mathbf{C a}(\mathbf{m M})$ & 1.2 to $2.9^{*}$ & 0.96 & 0.24 \\
Iron $(\mathbf{m M})$ & 0.003 to $0.018^{*}$ & $<0.00002$ & 0.00044 \\
$\mathbf{M g}(\mathbf{m M})$ & 3.7 to $4.9^{*}$ & 3.32 & 0.92 \\
$\mathbf{Z n}(\mathbf{m M})$ & 0.005 to $0.018^{*}$ & 0.0005 & 0.001 \\
$\mathbf{C u}(\mathbf{m M})$ & 0.003 to $0.006^{*}$ & 0.00098 & 0.00072 \\
$\mathbf{M n}(\mathbf{m M})$ & 0.001 to $0.002^{*}$ & $<4.18 \mathrm{e}-06$ & $<4.18 \mathrm{e}-06$ \\
\hline
\end{tabular}


Table 2. Sequences of the peptides identified in 10kDa EWF, 400Da EWR and 400Da EWF, divided in five groups based on the shortest common sequence. Antimicrobial property was predicted from the ADAM database using SVM (Support Vector Machine), or from the cAMP database using SVM, RF (Random Forest), ANN (Artificial Neural network) or DA (Discriminant Analysis); for each prediction method, peptides are regarded as antimicrobial (AMP) or not antimicrobial (NAMP). "Origin" indicates the protein from which each peptide originates, and "Fragment" indicates the positions of the first and last amino acid residues in the protein sequence. Physicochemical properties are either experimental (MW, molecular weight determined by mass spectrometry) or theoretical, predicted using ProtParam tools (MW; pI, isoelectric point; GRAVY, hydrophobicity index; Instability index), or Protein Calculator v3.4 (net charge at pH 7.0 and 9.0). Structure features predicted using APD3 (Antimicrobial Peptide Calculator and Predictor) are indicated as "Comments". Peptides selected for further study (P1-P4) are indicated in bold. 


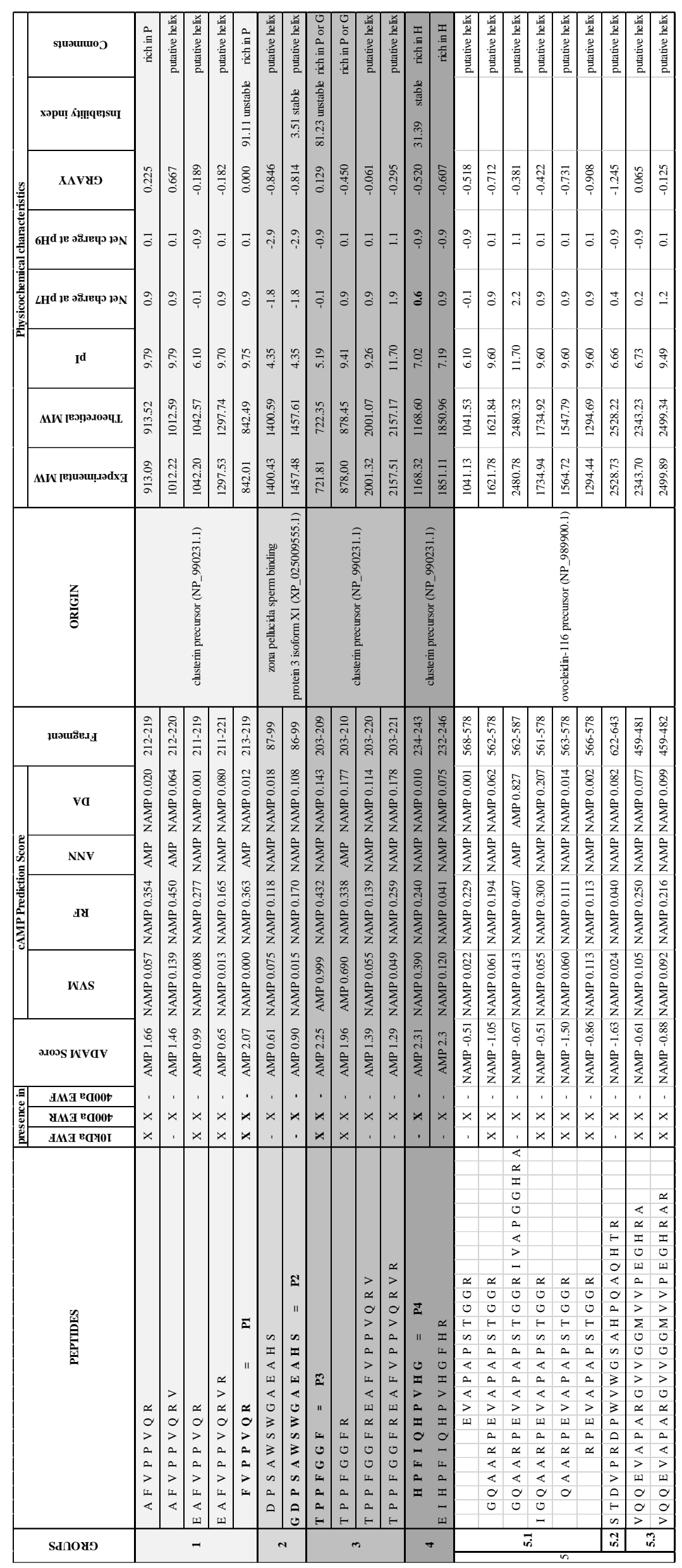


Figure 1. Flow chart of egg white (EW) fractionation by ultrafiltration and nanofiltration for the preparation of the $10 \mathrm{kDa}, 1 \mathrm{kDa}$, and 400Da egg-white filtrates (EWFs). Egg white retentates (EWRs) are the fractions retained by the membranes.

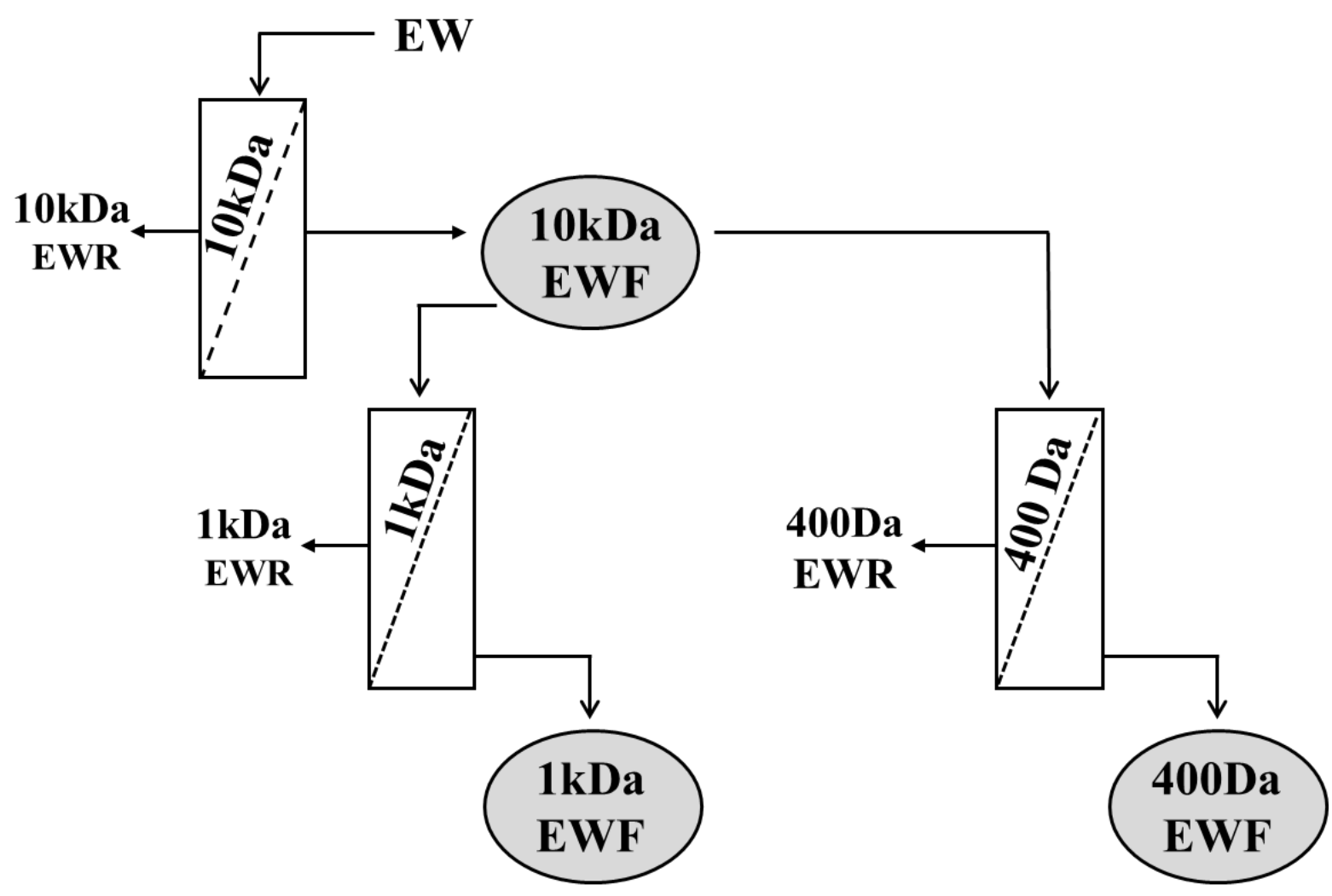


Figure 2. $S$. Enteritidis numeration after incubation for $24 \mathrm{~h}$ at $45^{\circ} \mathrm{C}(\mathrm{A})$ and $30{ }^{\circ} \mathrm{C}(\mathrm{B})$ in TSB $\mathrm{pH} 7.3$, egg white (EW) and $10 \mathrm{kDa}, 1 \mathrm{kDa}$ and $400 \mathrm{Da}$ egg white filtrates (EWFs). Bacteria were initially inoculated at $10^{6} \mathrm{CFU} / \mathrm{mL}$ (dotted line). Means and standard deviations were calculated from nine replicates (three biological replicates, each with three technical replicates). Samples with different letters display significantly different mean values ( $p<0.0001$ in $A, p<0.001$ in $B$ ).
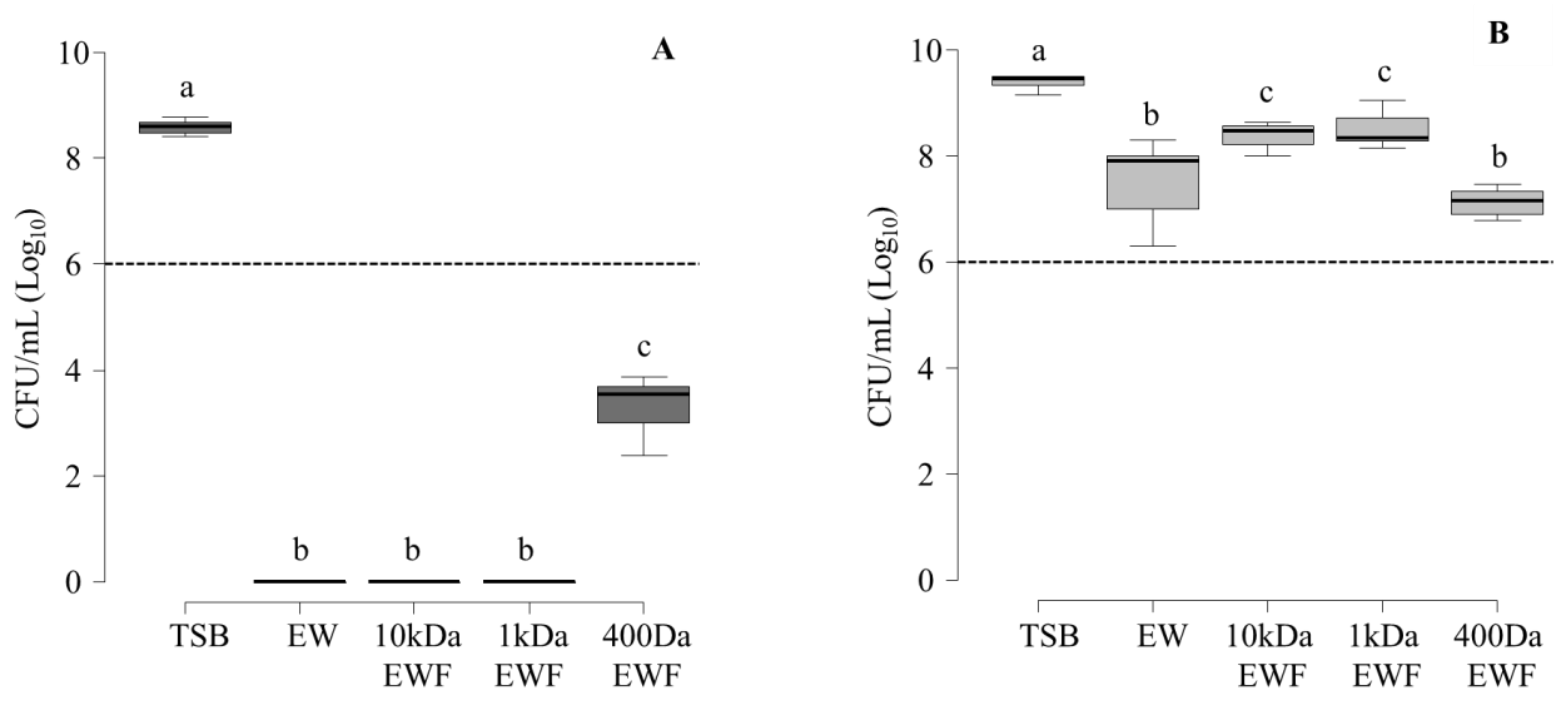
Figure 3. $S$. Enteritidis survival after incubation for $24 \mathrm{~h}$ at $45^{\circ} \mathrm{C}(\mathrm{A})$ and $30^{\circ} \mathrm{C}$ (B) in $400 \mathrm{Da}$ egg white filtrate (EWF) supplemented with increasing levels of the 400Da egg white retentate (EWR). Bacteria were initially inoculated at $10^{6} \mathrm{CFU} / \mathrm{mL}$ (dotted line). Means and standard deviations were calculated from nine replicates (three biological replicates, each with three technical replicates). Samples with different letters display significantly different mean values $(\mathrm{p}<0.001)$.
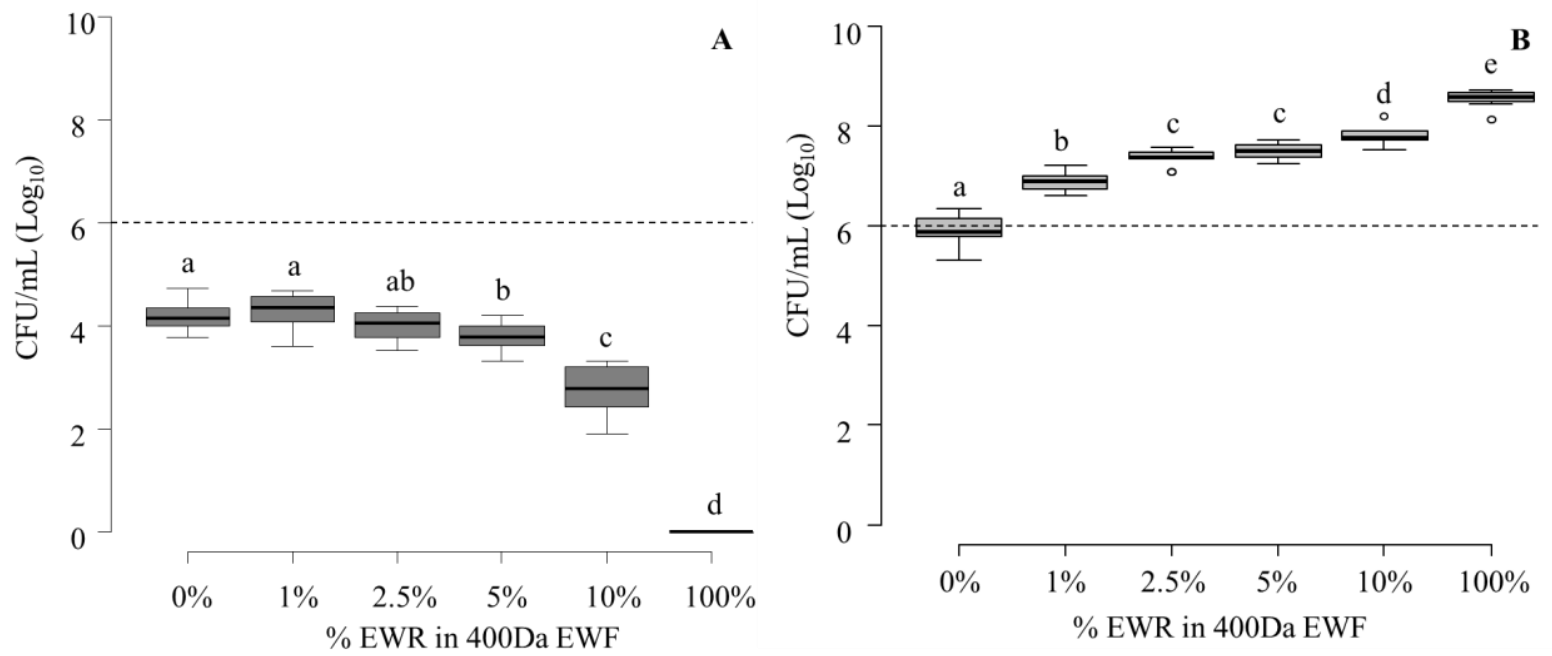
Figure 4. Effect of $\mathrm{pH}$, glucose and nitrogen levels on $S$. Enteritidis survival in the 400Da EWF. S. Enteritidis was incubated for $24 \mathrm{~h}$ at $45^{\circ} \mathrm{C}(\mathrm{A})$ or $30^{\circ} \mathrm{C}(\mathrm{B})$ in $10 \mathrm{kDa}$ EWF at pH 9.2, in 400Da EWF at pH 8.7 and 9.2, in 400Da EWF at pH 9.2 and with addition of a nitrogen (N) source and glucose (Glu) (up to $3 \mathrm{mM} \mathrm{N}$ and $25 \mathrm{mM}$ glucose). Bacteria were initially inoculated at $10^{6} \mathrm{CFU} / \mathrm{mL}$ (dotted line). Means and standard deviations were calculated from three technical replicates. Samples with different letters display significantly different mean values $(\mathrm{p}<0.01)$.
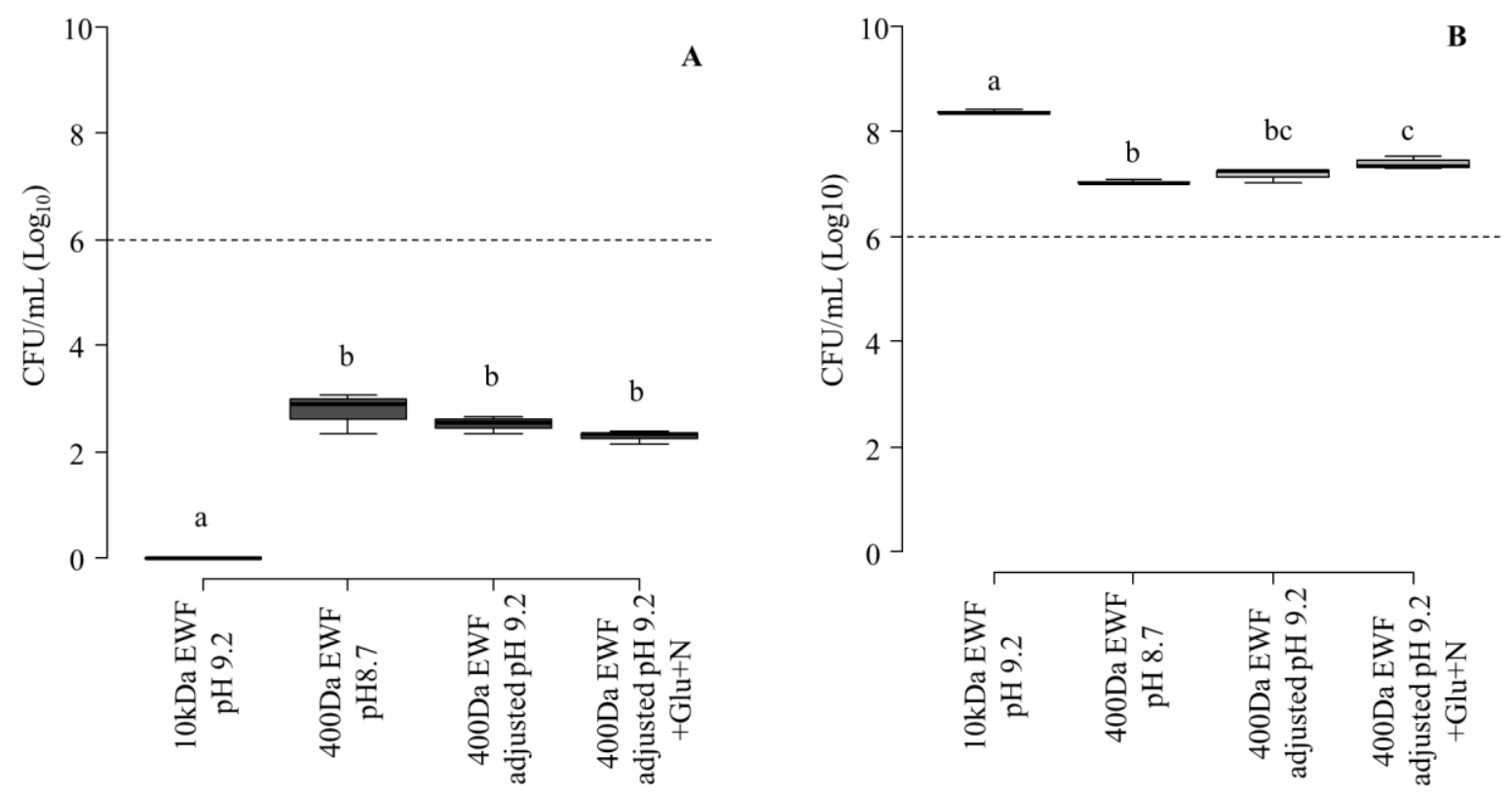
Figure 5. Effect of P1-P4 peptides on $S$. Enteritidis survival in 400Da EWF. S. Enteritidis was incubated for $24 \mathrm{~h}$ at $45^{\circ} \mathrm{C}$ (A) and $30^{\circ} \mathrm{C}$ (B) in TSB pH 7.3, 10kDa EWF, 400Da EWF, and 400Da EWF with addition of $100 \mu \mathrm{g} / \mathrm{mL}$ of the P1, P2, P3 or P4 synthetic peptides. Bacteria were initially inoculated at $10^{6} \mathrm{CFU} / \mathrm{mL}$ (dotted line). Means and standard deviations were calculated from three technical replicates. Samples with different letters display significantly different mean values $(\mathrm{p}<0.001)$.

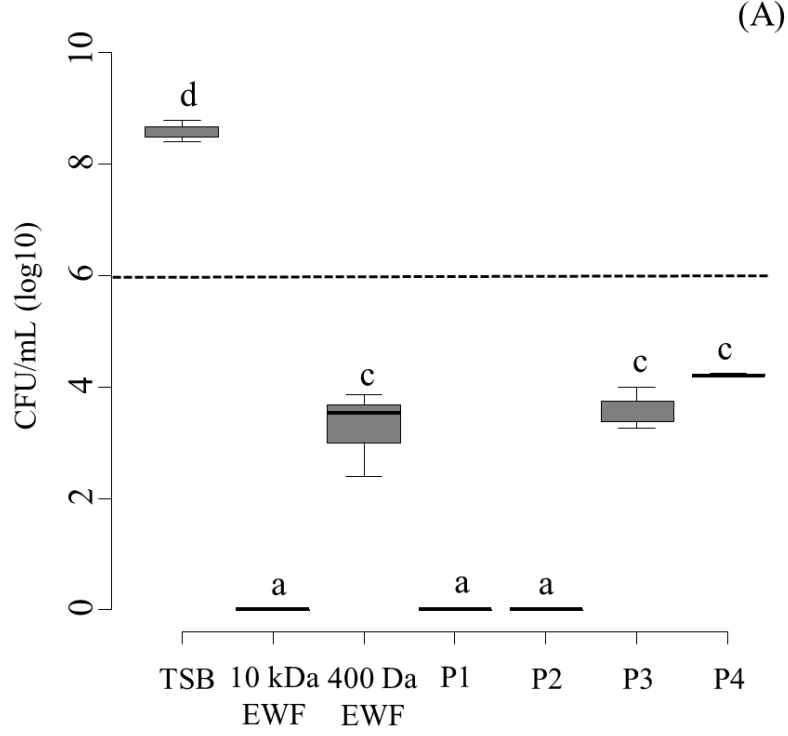

(A)

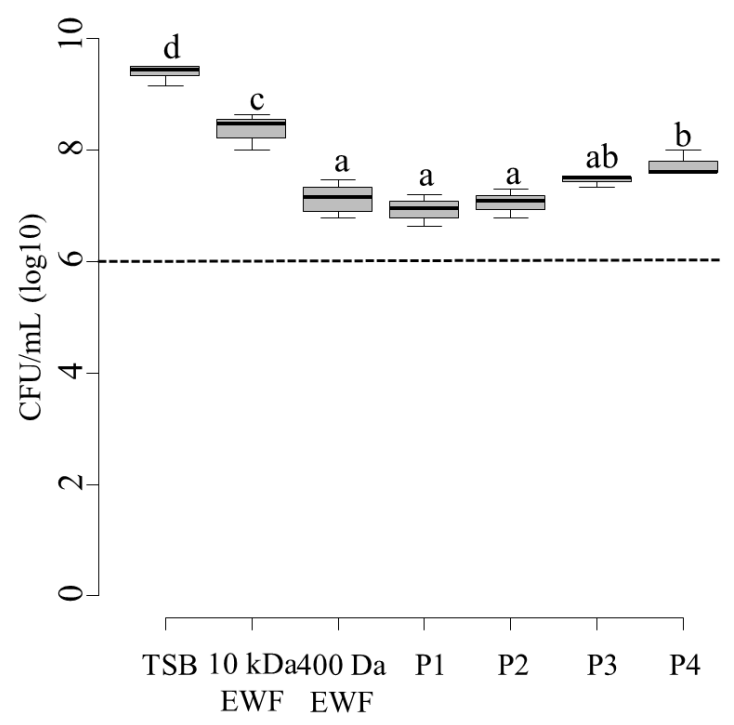


Figure 6. Effect of peptide concentration on the bactericidal activity of $\mathrm{P} 1$ and $\mathrm{P} 2$ against $S$. Enteritidis in 400Da EWF at $45^{\circ} \mathrm{C}$. P1 (A) and P2 (B) were added at 0 to $100 \mu \mathrm{g} / \mathrm{mL}$. Bacteria were initially inoculated at $10^{6} \mathrm{CFU} / \mathrm{mL}$ (dotted line). Means and standard deviations were calculated from six replicates (two biological replicates, each with three technical replicates). Samples with different letters display significantly different mean values $(\mathrm{p}<0.01$ for $\mathrm{A}$, and $\mathrm{p}<0.001$ for $\mathrm{B})$.
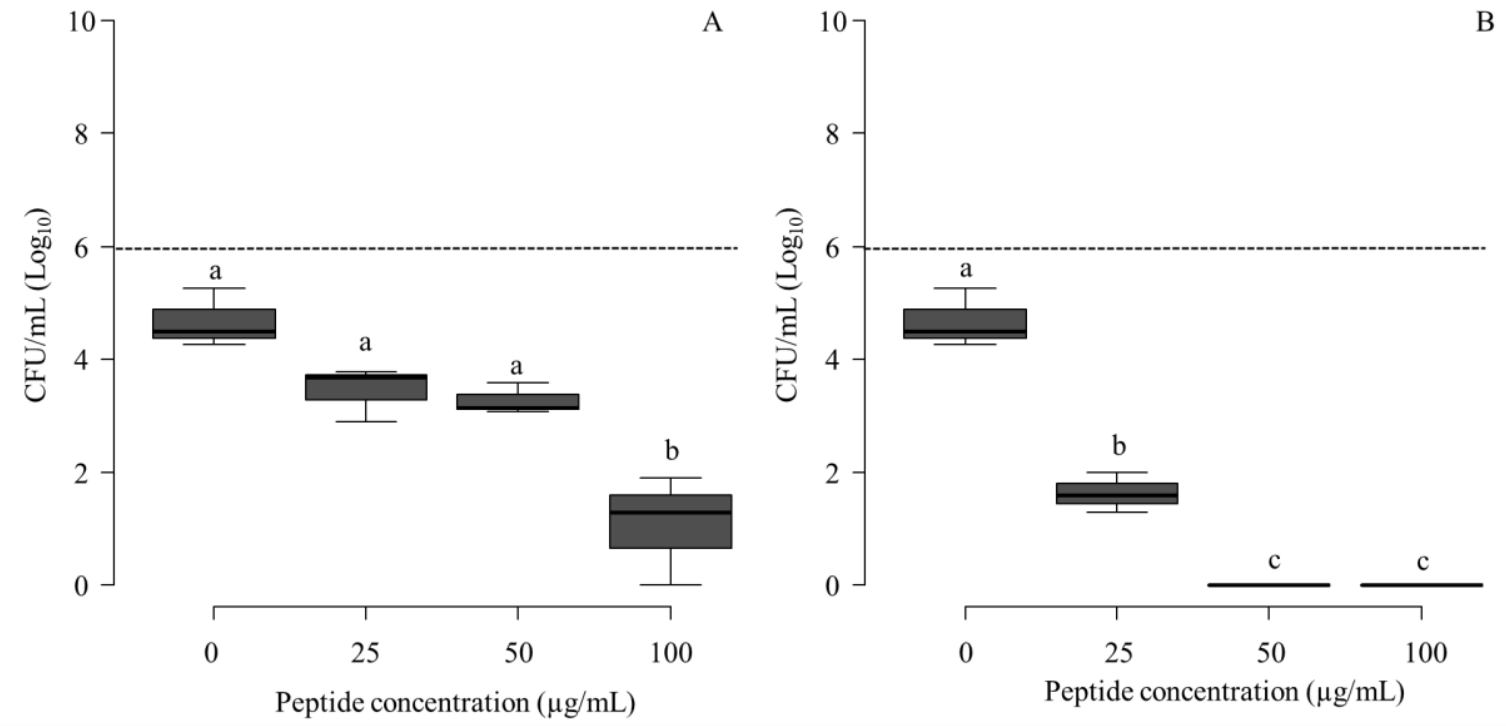
Figure 7: Effect of both AMPs P1 and P2 on $S$. Enteritidis survival in M63 minimal medium and in 400Da EWF. S. Enteritidis was incubated for $24 \mathrm{~h}$ at $45^{\circ} \mathrm{C}$ in $\mathrm{M} 63$ at $\mathrm{pH} 7.8$ and 9.2, and in 400Da EWF, with or without addition of $100 \mu \mathrm{g} / \mathrm{mL}$ P1 or P2. Bacteria were initially inoculated at $10^{6} \mathrm{CFU} / \mathrm{mL}$ (dotted line). Means and standard deviations were calculated from three technical replicates. Samples with different letters display significantly different mean values $(\mathrm{p}<0.001)$.

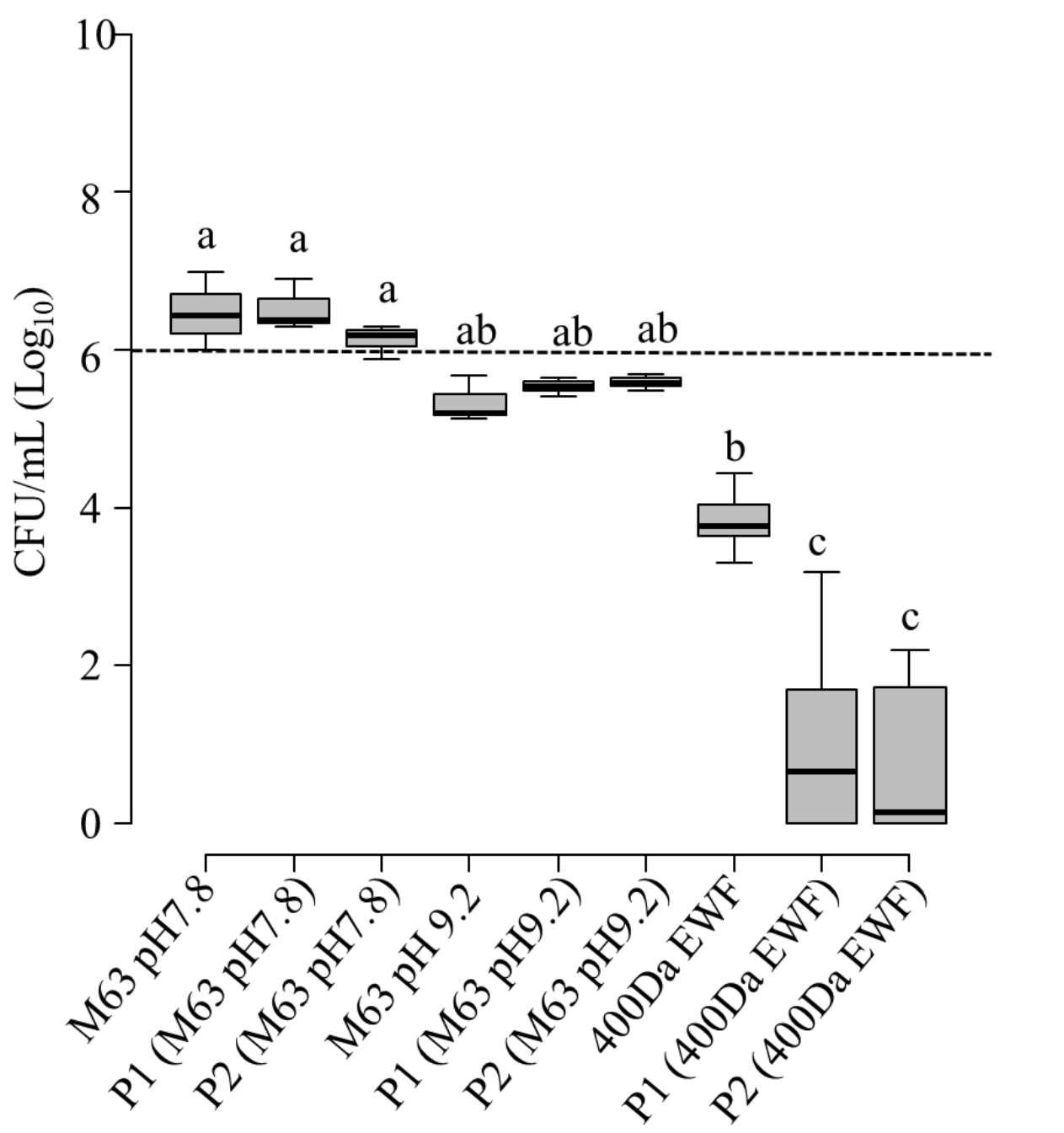


Figure 8. Synergistic bactericidal effect of the AMPs $\mathrm{P} 1$ and $\mathrm{P} 2$ against $S$. Enteritidis at $45^{\circ} \mathrm{C}$ in 400Da EWF. $S$. Enteritidis was incubated for $24 \mathrm{~h}$ at $45^{\circ} \mathrm{C}$ in $400 \mathrm{Da}$ EWF with addition of P1 $(25 \mu \mathrm{g} / \mathrm{mL}), \mathrm{P} 2(25 \mu \mathrm{g} / \mathrm{mL})$, or P1+ P2 $(12.5 \mu \mathrm{g} / \mathrm{mL} \mathrm{P} 1 ; 12.5 \mu \mathrm{g} / \mathrm{mL}$ P2). Bacteria were initially inoculated at $10^{6} \mathrm{CFU} / \mathrm{mL}$ (dotted line). Means and standard deviations were calculated from three technical replicates. Samples with different letters display significantly different mean values $(\mathrm{p}<0.001)$.

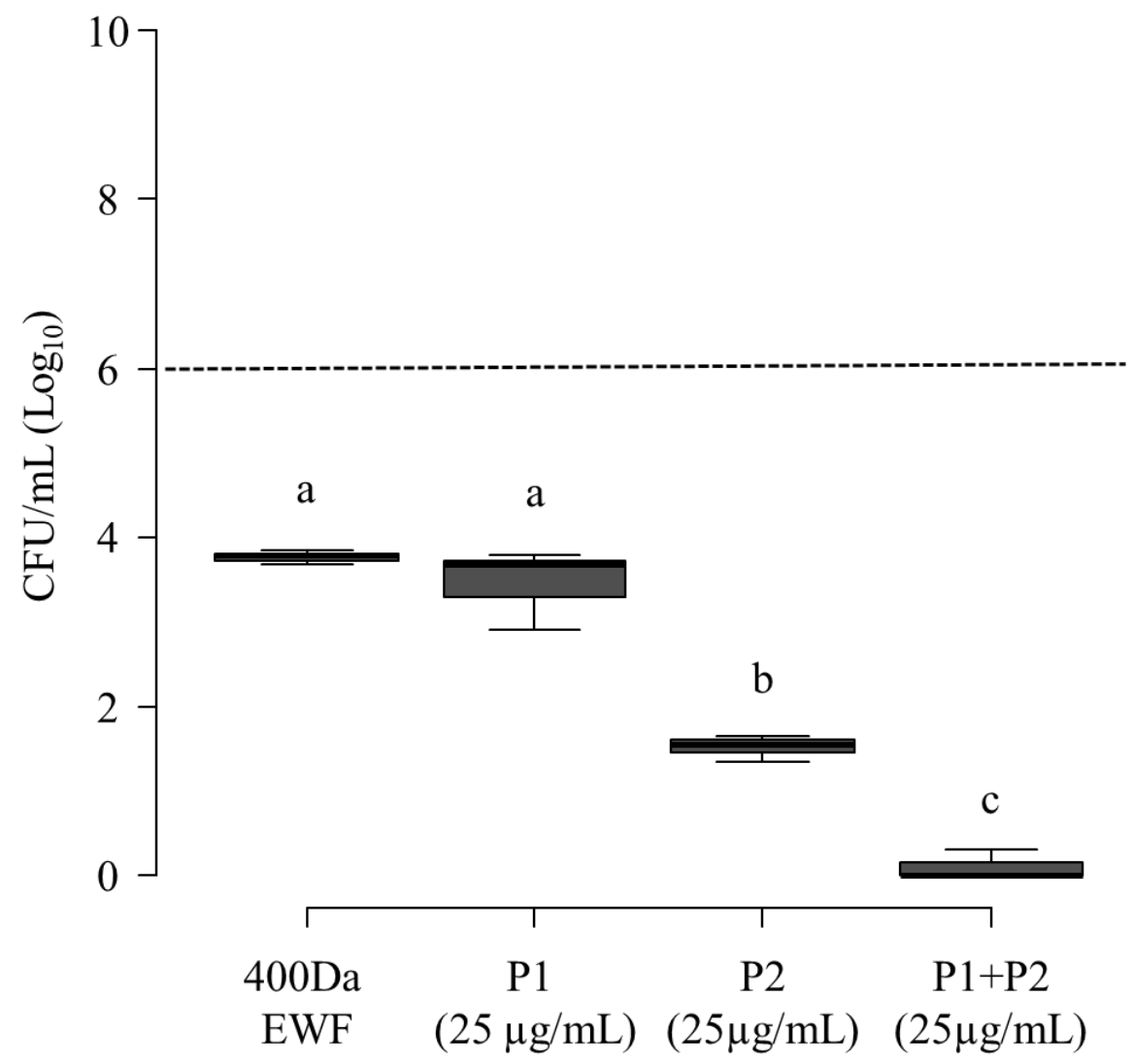




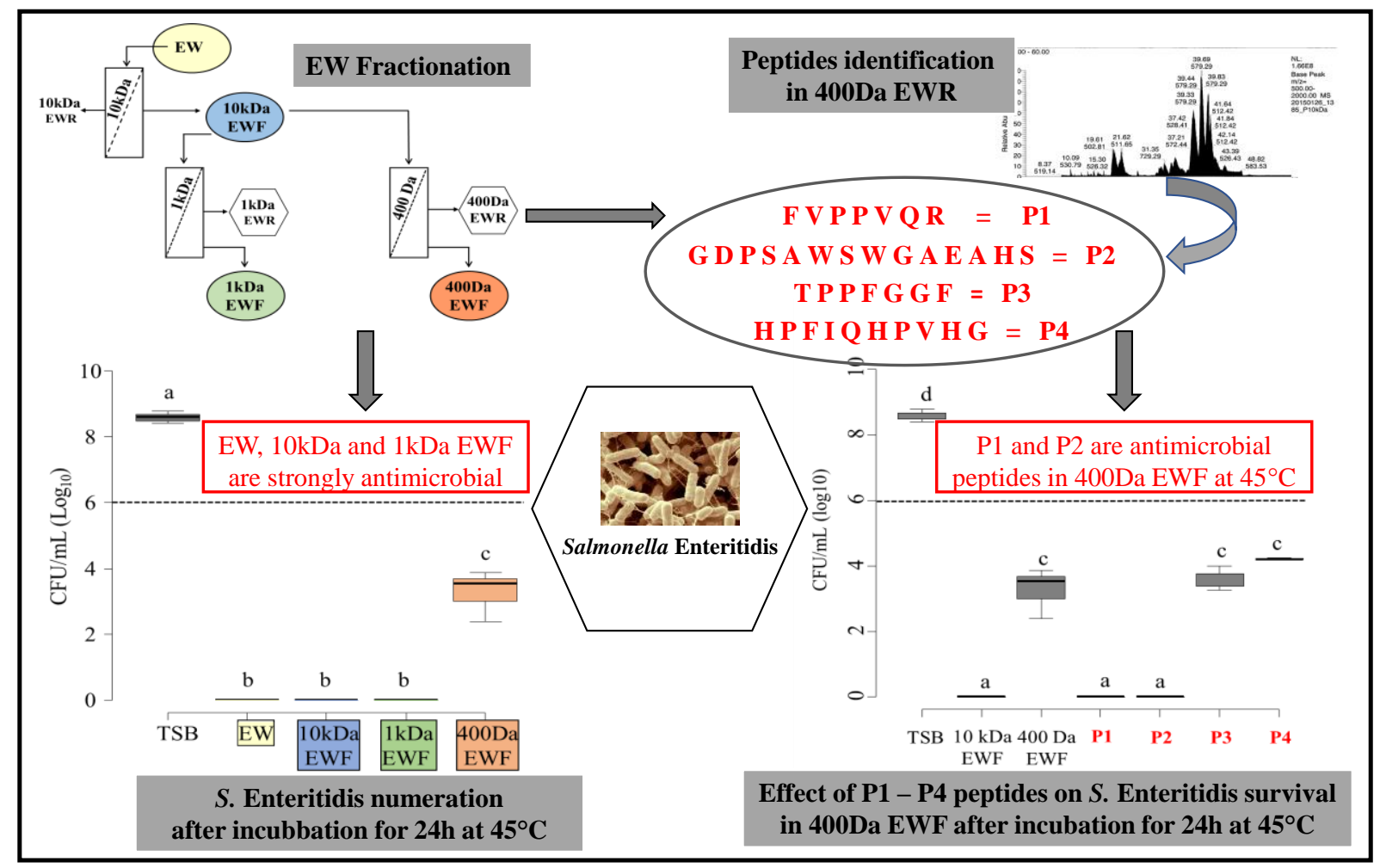

